\title{
Ortaöğretim Öğrencilerinin Barış ve Savaş Kavramına Yönelik Görüşleri ${ }^{1}$
}

\author{
Yrd. Doç. Dr. Özgür AKTAŞ \\ Kafkas Üniversitesi, Eğitim Fakültesi, Sosyal Bilgiler Eğitimi Anabilim Dalı, Kars / Türkiye
}

\section{Özet}

$\mathrm{Bu}$ çalışmanın amacı ortaöğretim öğrencilerinin savaş ve barış kavramına yönelik düşüncelerini ortaya çıkarmaktır. Çalışma görüşme yöntemine dayanmaktadır. Çalışmanın modeli ise tarama modelidir. Bu çalışma kapsamında yedi okul türünden on öğrenci ile görüşme yapılmıştır. Öğrencilerin savaş kavramına yönelik tutumları ve bilgilerini öğrenme için yarı yapılandırılmış görüş̧e formu kullanılmıştır. Çalışmanın sonuçları değerlendirildiğinde öğrenciler savaş ve barış kavramını geniş bir yelpazede değerlendirmiştir. Öğrenciler dünyada barışın gerçekleşebilmesi için gelir farkının azaltılması ve ayrımcılıkların ortadan kaldırılması gerektiğini düşünmektedir. Öğrencilere göre dünyadaki savaşların başlıca nedenleri arasında gelişmiş ülkelerin Ortadoğu petrollerine el koyma isteği vardır. Az gelişmiş ülkelerdeki demokrasi eksikliği de dünya barışını tehdit etmektedir.

\footnotetext{
${ }^{1}$ Bu çalışma 2012 yılında Mustafa SAFRAN danışmanlı̆̆ında hazırlanan "Tarih Eğitiminde Savaş ve Barış" adlı doktora tezinin bir bölümünden düzenlenmiștir.

* Tel: +90 $4742251434 \quad$ E-posta: ozgurkafkas@gmail.com

(C) 2014 Kalem Eğitim ve Sağlık Hizmetleri Vakfı. Bütün Hakları Saklıdır. ISSN: 2146-5606
} 
Anahtar Kelimeler: Savaş; Savaş ve barış; Tutum ölçeği; Tarih eğitimi; Öğrenci.

\title{
High School Students' Opinions Related to Peace and War Concept
}

\begin{abstract}
The aim of this study is to put forth the thoughts of secondary school students on war and peace concepts. The study is based on interview method. The model of this study is survey model. For this aim, in seven types of schools, 10 students participated in the interview. In order to learn the knowledge and attitudes of students regarding the issues of war and peace, a semi-structured interview scale was used. When the results of the research were considered, students evaluated the concepts of war and peace with a wide perspective. For the realization of the global peace, students think that income gap should be reduced and elimination of the discrimination must be done. According to students the main causes of war are that developed countries aim at invading Middle East oil sources and lack of democracy in under developed countries.
\end{abstract}

Keywords: War; War and peace attitude scale; Interview scale; History education; Student.

\section{Extended Summary}

\section{Purpose}

War and peace heve been importent parts of human life through the history of humanity. The purpose of the this study is to determine the opinions of secondary education students regarding war and peace issues. 


\section{Methods}

The ideas of students were elicited through a semi-structured interview scale that was formed for this purpose. A semi-structured interview scale provides "flexibility for the researchers and enables them to carry out the interviews without interruption. Interviews were carried out with ten students from each of seven different schools. Thirty-five girls and 35 boys were included in the research. These were all high school students. Before the interviews, teachers consulted and asked to direct researchers to students who could express themselves well verbally. The reason for this was that the interviews would be lengthy and there was a need for truly information. The analysis of the data obtained through the interviews was made with a coding system prepared beforehand. The interview scale and coding system used for this study was prepared by Ilse Hakvoort. One of the most important features of scale used in this study is that the concepts of war and peace could be taken into consideration both at a personal level and an international level. Necessary permission was obtained to be able to use the scales.

\section{Results and Discussion}

As a result to analysis regarding the findings in the research, a large range of categories in the definitions of the students regarding war and peace were found. Most of the students defined peace with positive terms. On the other hand, the students defined the concept of peace with war in the second category. In other words, the concept of peace reminded them of war in this category. The secondary school students 
answered the question of what should be done in order to make the world a peaceful place in a striking way, that needy people should be helped. The students also emphasized that as for peace there should be no discrimination against people. They also pointed out that the government must join the public in the case of a civil war in a country. The students answered the question "Is there peace in the world?" by claiming that there isn't equal peace around the world, as there is peace in some places but not in other places. Only $1.9 \%$ of the students gave the answer that there is peace in the world. The students were pessimistic about the presence of peace in the world. In addition, the students believed that the factor contributing most to peace in Turkey is politics. They pointed out that the public is in second place in this regard in Turkey.

In the qualitative data obtained, it was found that secondary school education students pay special attention to the defense of the country. Most students answered the question "What should a boy at the age of fifteen do if he is allowed to decide to join a war?" by saying he should not join the war. When asked "What would you do if you were that child?" they answered at a high rate that they would go to war. The students were also asked why a boy at the age of fifteen might not be able to join a war. They answered that he might be afraid of war; he might feel that he is physically weak. Additionally, they gave the answer that he might not join the war as there is no love connection between the boy and his country.

The students were asked what they would do if one of their be- 
longings was used by a friend of theirs. They answered this question by saying that they would appeal to an authority figure at a high rate. The students pointed out that the most important factor is a mediator to make peace in the case of a fight between friends at school and when two countries are at war with each other. In light of these findings, it can be said that the students think positively about the efforts of such organizations as United Nations and UNESCO.

The students answered the question "Which wars took place in the 20th century?", first with World War II, then World War I, and finally the War of Independence. The students were more interested in the War of Independence and why they mentioned the War of Independence in third place even though it is specifically emphasised in the curriculum that they perceive the War of Independence within the World War I. They most frequently gave the example of the Gulf War as for an international war. Second, the students named the Israeli-Arab wars, putting the clashes between Israel and Palestine at the center. The students mentioned the Korean War as the third example. The most important reason for this was that Turkey sent troops for the Korean War. They mentioned the war between Russia and Georgia at least. The reason why very few students mentioned this war was that the war lasted for a very short time and they were too young to focus on this war while the war was going on. The war between Russia and Georgia is the only war that happened after the current study started. The students knew equally about the wars between Russia and other countries after the collapse of Bosnia, Montenegro and the Soviet Union. The striking 
point here is that the students were able to focus on the wars between Russia and other Slavic countries after the collapse of the Soviet Union.

When they are asked about countries that experienced civil war, the students gave Palestine as an example at the highest rate and this was followed by Israel. In third place was Iran. It is thought that the clashes between Israel and Palestine had an impact on children in their answers of countries that have experienced civil war. They replied the question with various countries of Africa at a very low rate. It is clear that the press, television and the internet had a significant impact on the formation of the ideas of the students about these wars. Additionally, there is an important problem with teaching African history in high schools. The students gave Libya, Egypt and Syria as examples of current sites of civil war. In early October 2011, when the research was carried out, there was a lot of news about Libya in the press. The clashes in Egypt had just calmed down and those in Syria were about to intensify. The students named Iraq and then Tunisia, where the so-called "Arab Spring" of riots against the regime started. While a student mentioned the civil war in Yemen, another student paid attention to the clashes in Greece. The secondary school students described the current civil wars at a high rate as a result of the intentions of superpowers to obtain the petroleum of other countries. These powers were defined as western countries. The students also indicated the problems experienced between the people and those ruling the country.

\section{Conclusion}

Finally, they mentioned that there were no universal rights in 
these countries. Depending on the findings, it is likely that nearly half of the students thought that the so-called "Arab Spring" was organized by external and superpower states. However, the students indicated secondly that these countries have civil wars due to the fact that there are dictators ruling the countries and there are no universal rights. That is to say, the students had two different ideas about the things experienced in the Arab countries recently.

In terms of the literature, it is clear that there is a shortage of studies carried out in the field of educational sciences regarding the concepts of war and peace. There is a need for research into the age at which students can define the concepts of war and peace. In addition, there is much more need for research aiming at the nature and definitions of war and peace.

Testing methods and techniques is needed to be clarified the concepts of war and peace by students. Studies related to perceptions of students on war and treat are needed. While these studies are done, it is important that war and peace should be evaluated one by one.

\section{Giriş}

İnsanlığın en eski tarihinden itibaren savaş ve barış kavramının var olduğu bilinmektedir. İnsanlık, bir taraftan savaş yaparken bir taraftan da barışa ulaşma çabası içerisindedir. Savaş kelimesi çok değişik anlamlar ifade etmektedir. Kimilerine göre savaş yok edilmesi gereken bir kötülüktür. Bazılarına göre ise savaş insanlığın kaçınamayacağı bir yazgıdır. Savaşı insanlığın ilerlemesi için bir araç olarak görenler de 
vardır (Wright, 1941, s.3). Hesiod, savaşı Zeus'un bir cezası olarak tanımlamıştır. Heredot ise savaşı çocukların babalarını gömmelerinden daha çok, babaların çocuklarını gömdüğü zaman olarak nitelendirmiştir (Hanson, 1999, s.191). Savaş aynı zamanda kavga, muharebe, mücadele, harp kavramlarıyla da ilişkilendirilmiştir (Akad, 2011, s.9).

Barış ve savaş kavramıyla ilgili dünyanın çeşitli ülkelerinde önemli çalışmalar yapılmıştır. Porter'ın (1926) Amerika Birleşik Devletleri’nde, üniversite öğrencilerinin savaş hakkındaki görüşlerini ortaya çıkarmak için yaptığı çalışma, alanda tespit edilen ilk tez çalışmasıdır. Barış ve savaş konularında meslek önemli bir değişken olarak kabul edilmektedir. Pihlblad (1935), çalışmasında üniversite öğrencilerinin, babalarının mesleğine ve ailelerinin aylık gelirlerine göre savaşı tanımlamaları arasında anlamlı bir farklılığın olmadığı ortaya çıkmıştır. Stagner (1942) yaptığı çalışmada askerlik mesleğiyle uğraşmanın savaşlara karşı tutumda anlamlı bir fark yarattığı sonucu ortaya çıkarmıştır. Barış ve savaş kavramlarına bakış açısında cinsiyetin de önemli bir değişken olduğu görülmüştür. Duffy'nin (1941) yaptığı çalışmada, kadınların erkekler oranla savaş ve cezalar konusunda daha 1lımlı bir tutuma sahip oldukları görülmüştür. Gwartney ve Lach (1991) tarafından yapılan çalışmada, kadınlar daha fazla oranda nükleer savaşa karşı iken, nükleer savaşın çıkacağına erkeklerden daha fazla oranda inandıkları sonucu ortaya çıkmıştır. Hakvoort'un (1996) çalışması Hollandalı çocuklar ile olmuştur. Çalışma cinsiyet açısından değerlendirildiğinde erkeklerin kızlara oranla barış kavramını daha kısa sürede kavrayabildikleri görülmüştür. 
Barış ve savaş kavramlarını anlamlandırabilmede yaş en önemli değişkenler arasındadır. Cooper (1965) tarafından yaşları yedi ile on altı arasında değişen İngiliz ve Japon öğrencilerin savaşlara bakış açısını karşılaştırmak için bir çalışma yapılmıştır. Yaşları küçük öğrenciler savaşı genellikle silahlar, helikopterler, gemilerle tanımlamıştır. Rosell ise (1968) İsveç’te 8, 11 ve 14 yaş arasındaki çocuklarla savaş ve barış kavramı ile ilgili bir araştırma yapmıştır. Araştırmada çocukların barış kavramını savaş kavramı kadar açıklayamadıklarını ortaya çıkarmıştır. Vriens ve Aspeslagh (1985) ise, 6-7 yaş öğrenciler ile savaş ve barış kavramı konusunda çalışma yapmıştır. Bu çalışmada da barış kavramını ifade etmenin savaş kavramını ifade etmekten daha zor olduğu ortaya konmuştur. Rodd, 1985 yılında 4-6 yaş anaokulu öğrencileriyle savaş kavramı ile ilgili çalışma yapmıştır. Yapılan çalışmada bu çocukların çok azının savaş kavramını ifade edebildiği görülmüştür. Hakvoort ve Oppenheimer (1993), Hollandalı ve İsveçli öğrenciler ile savaş ve barış kavramı hakkında görüşme yapmıştır. Öğrencilerin yaşları 8 ile 17 arasında değişmiştir. On yaşından küçük öğrenciler barışı yaşadıkları çevre ile özdeşleştirirken, on yaşından sonraki öğrenciler barışı evrensel bir hak olarak tanımlamaya başlamıştır. Kız öğrenciler savaşı, askerler ve silahlarla tanımlamışlardır. Covel, Krasnor, Fletcher 1994 yılında Kanada'da yaşları 7 ile 18 arasında değişen 156 öğrenci ile çalışma yapmıştır. Öğrencilerin cevapları somut cevaplar, soyut cevaplar ve genel cevaplar olarak gruplandırılmıştır. Öğrencilerin soyut kavramları 11 yaşından sonra kullandıkları görülmüştür. Öğrencilerin savaş kavramını, barış kavramından daha iyi tanımlayabildikleri ortaya çıkmıştır. 
Cantril, Rugg ve Williams 1940 yılının Temmuz ve Ekim aylarında iki kez çalışma yaptılar. Bu çalışma kamuoyunun İkinci Dünya Savaşı'na ABD'nin katılmasıyla ilgili görüşlerin 4 ay gibi kısa sürede değiştiğini göstermesi bakımından önemlidir. Preston (1942) tarafından ABD'nin İkinci Dünya Savaşı'na girmesinden önce yapılan araştırmada, Amerikan çocuklar en fazla Adolf Hitler'i tanıdıklarını söylemiştir. Kuhlen (1943) ABD'de yaptığı araştırmada ABD'li öğrenciler en olumsuz kavramlarla Japonya ve İtalya'y1, en olumlu kavramlarla Çin ve Büyük Britanya'yı ilişkilendirmiştir. Hakvoort (1996) tarafından yapılan başka bir çalışmada 161 ilköğretim öğrencisiyle görüşülmüştür. Çalışmada ülke anlamında öğrenci cevapları arasında farklılık olmuştur. Hollandalı öğrenciler barışı, İsveçli öğrencilerden daha fazla oranda "negatif barış" ile tanımlamışlardır. İsveçli öğrenciler ise barışı, genellikle savaş ve savaş aktivitelerinin yokluğu ile ilişkilendirmişlerdir.

Alvik (1968) tarafından yapılan çalışmaya göre öğrenciler yaşadıkları dönemde devam eden savaşlarla ilgili haberleri akranlarından, gazetelerden, radyo ve televizyonlardan öğrenmişlerdir. Buna karş1 öğrenciler barışı da savaşlardan öğrenmişlerdir. Berti ve Vanni (2000) tarafından İtalyan çocukları ile savaş kavramı ile ilgili çalışma yapılmıştır. Yapılan çalışmada çocukların savaşı tanımlamasında sosyal organizasyonları bilmelerinin önemli olduğu görülmüştür.

Türkiye'de savaş kavramıyla ilgili pek çok araştırma yapılırken savaş ve barış konusuyla ilgili uygulamalı araştırmaların eksik olduğu görülmektedir. Savaş ve barış konusunda uygulamalı araştırmaların 
Amerika Birleşik Devletleri’nde yirminci yüzyılın ikinci çeyreğinde başladığı görülmektedir.

\section{Çalışmanın Amacı}

$\mathrm{Bu}$ çalışmanın amacı ortaöğretim öğrencilerinin savaş ve barış kavramının doğasına ilişkin görüşlerini ortaya koymaktır.

\section{Çalışmanın Soruları}

1. Ortaöğretim öğrencilerinin savaş ve barış kavramının doğasına ilişkin görüşleri nelerdir?

2. Ortaöğretim öğrencileri 20. ve 21. yüzyılda meydana gelen hangi savaşlar hakkında bilgi sahibidirler ve günümüzdeki savaşların nedenlerine ilişsin görüşleri nelerdir?

\section{Yöntem}

\section{Araştırmanın Modeli}

Çalışma bir nitel çalışmadır. Çalışmada yarı yapılandırılmış görüşme yöntemi kullanılmıştır. Çalışmanın modeli ise tarama modelidir. Tarama modeli geçmişte ya da hâlen var olan durumu var olduğu şekliyle betimlemeyi amaçlayan araştırma yaklaşımıdır (Karasar, 2005, s.77).

\section{Çalışma Grubu}

Çalışma Ankara'da farklı okul türünde gerçekleştirilmiştir. Yedi okuldan 10'ar kişi olmak üzere 35 bayan 35 erkek son sınıf öğrencisiyle görüşme yapılmıştır. Görüşmenin uzun olması ve görüşmede akıcılığın sağlanması adına öğretmenlerle görüşülerek sözel olarak kendilerini en 
iyi ifade edebilen öğrencilerin görüşmeye yönlendirilmesi istenmiştir. Görüşme yapılan okul türleri şöyledir: Atatürk Anadolu Lisesi (AL), Gazi Çiftliği Lisesi (GL), Tevfik İLERİ İmam Hatip Lisesi (İHL), Ankara Fen Lisesi (FL), Yenimahalle Güzel Sanatlar ve Spor Lisesi (GSSL), Sosyal Bilimler Lisesi (SBL), Zübeyde Hanım Kız Meslek Lisesidir (ML).

\section{Veri Toplama Aracı}

Ortaöğretim öğrencilerinin savaş ve barış kavramları ile ilgili görüşlerini öğrenebilmek amacıyla öğrencilerle görüşme yapılmıştır. Araştırmada yarı yapılandırılmış görüşme formu kullanılmıştır. Yarı yapılandırılmış görüşmeler bir konuda kavramlar oluşturmak için elverişlidir (Tashakkori ve Teddlie, 2009, s.297). Görüşme soruları (Interview-Manual) Ilse Hakvoort tarafından geliştirilmiştir. Bu görüşme soruları ve kodlama sisteminin kullanılması için araştırmacıdan gereken izin alınmıştır. Görüşme soruları ve kodlama sistemi Türkçeye çevrilmiştir. $\mathrm{Bu}$ görüşme ölçeği kullanılmadan önce alanda üç uzmandan ve Türkçe bölümünden bir uzmandan görüş alınmıştır. Görüşmenin akışına göre sonda sorulardan da yararlanılmıştır. Öğrencilerin verdikleri cevapların yüzde olarak oranları grafik ve tablo hâlinde verilmiştir.

\section{Verilerin Toplanması}

Çalışma Ankara ilinde 2011-2012 eğitim öğretim yılının güz yarıyılında gerçekleştirilmiştir. Çalışmada ortaöğretim son sınıf öğrencileriyle teker teker görüşülerek veri toplanmıştır. Veriler ses kayıt cihazıyla kaydedilmiş daha sonra görüşme yazıya aktarılmıştır. 


\section{Verilerin Analizi}

Öğrencilerin verdikleri cevaplar Ilse Hakvoort tarafindan geliştirilen kodlama sistemi ile kodlanmıştır. Öğrencilerden alınan cevaplar içerik analizi ile değerlendirilmiştir. İçerik analizi toplanan verilerin önce kavramsallaştırılması, daha sonra ortaya çıkan kavramlara göre mantıklı biçimde düzenlenmesi ve buna göre veriyi açıklayan temaların saptanması gerekmektedir (Yıldırım ve Şimşek, 2006, s.227). Bu çalışmada bir öğrencinin verdiği cevap, kayıp veriler olabileceği gibi, bir kategori ya da birden daha fazla kategoride olabilmektedir. Ölçeğin daha iyi anlaşıılması için çalışmanın birinci sorusu örnek olarak verilebilir: "Barış nedir?" diye sorulduğunda eğer öğrenci savaşla ilgili cevaplar vermişse bu öğrenci barışı savaşla ilişkilendirmiş olmakta ve cevabı kategori 1'e dâhil olmaktadır. Eğer öğrenci "barış nedir" sorusuna "ayrımcılıkların olmaması, ırkçılığın olmaması" gibi cevaplar verirse bu cevaplar kategori 6'da insan tutumları başlığı altına yerleştirilmektedir. Eğer öğrenci barışı silahların olmaması ya da silahların azaltılması ile ilişkilendirmişse öğrencinin cevabı kategori 5 'te (silahsızlanma) değerlendirilmektedir. Öğrencilerin verdikleri cevaplardan örnekler verilirken bayan öğrenciler B, erkek öğrenciler ise E ile tanımlanmaktadır. Ayrıca öğrencilerin hangi okuldan olduklarını belirtmek için ise öğrencilerin öğrenim gördükleri okulların baş harfleri verilmiştir. Örneğin (GL, B) öğrencinin genel lisede öğrenim gördügünü ve bayan olduğunu ifade etmektedir.

\section{Bulgular ve Tartışma}

Çalışmanın bu bölümünde araştırmadan elde edilen veriler ortaya 
konarak öğrencilerin görüşme sorularına verdikleri cevaplardan örnekler sunulacaktır.

\section{Ortaöğretim Öğrencilerinin Savaş ve Barış Kavramının Doğasına İlişkin Görüşleri Nelerdir?}

Çalışmanın birinci sorusu öğrencilerin savaş ve barış kavramının doğasına ilişkin görüşlerini öğrenmeye yöneliktir. Bu kapsamda öğrencilere on iki alt soru sorulmuş, alınan cevaplar kategorilere ayrılarak grafikler halinde sunulmuştur.

\section{Barış nedir? Barış kelimesi size neyi hatırlatmaktadır?}

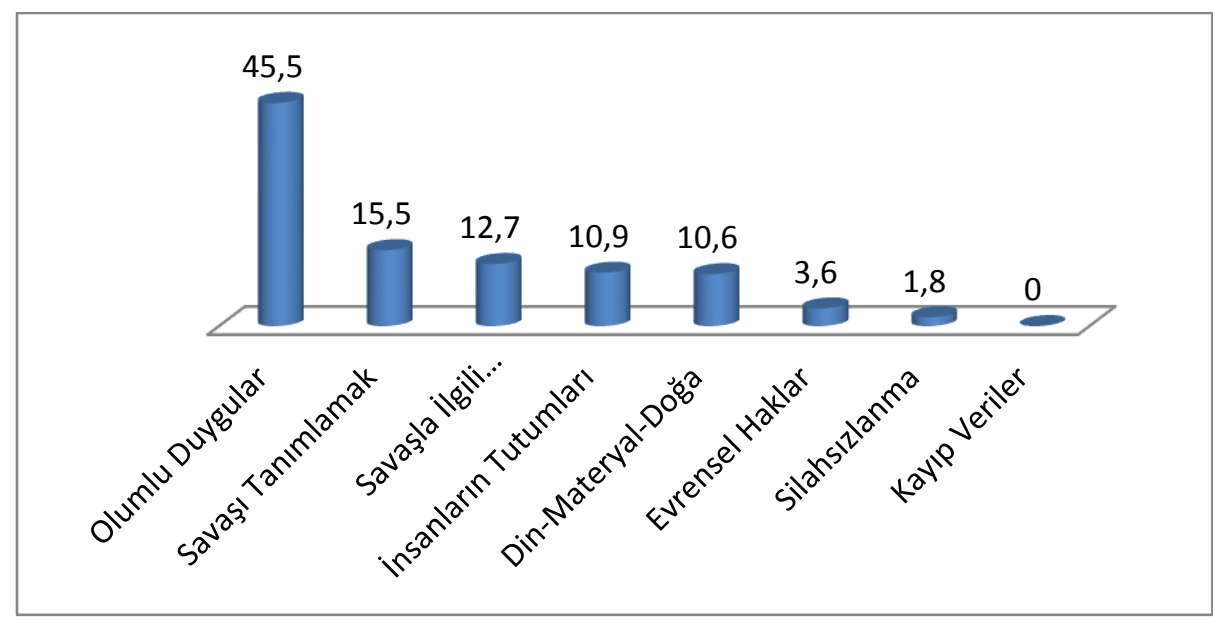

Grafik 1. Öğrencilerin Barış Kavramı ile İlgili Tanımları

Grafik 1'de görüldüğü gibi ortaöğretim öğrencilerinin \% 45.5'i barış1, olumlu duygular (Kategori 3) olarak tanımlamıştır. Çalışmada olumlu duygular, kişisel düzeyde olumlu duygular ve evrensel düzeyde olumlu duygular olmak üzere ikiye ayrılmaktadır: Kişisel düzeyde olumlu duygular $39 \mathrm{kez}$, evrensel düzeyde olumlu duygularsa $11 \mathrm{kez}$ 
tekrarlanmıştır.

"Barış kelimesi aklıma her zaman "Yurtta sulh cihanda sulh" anlayışını ve Kemal Atatürk’ü getirir” (GL, B). "Barış, dünya üzerindeki bütün milletlerin huzurlu, mutlu yaşamasıdır (GL, B). "Birlik, beraberlik, huzur"(IHL, E).

Brezilya'da Souza, Sperb ve McCarty (2006, s.55) yaptığı ça1ışmada öğrenciler barışı en fazla mutluluk, sevgi, bir arada olma ifadelerinin yer aldığı olumlu duygularla tanımlamıştır. Bu anlamda iki çalışmanın sonuçları benzerlik göstermektedir.

Öğrencilerin \% 15.5'i ise ikinci sırada barışı savaş ile (Kategori 1) ilişkilendirdiler ya da negatif barışa vurgu yapmıştır.

"Barış kelimesini duyduğum zaman savaşın mantıksız olduğu aklıma gelir” (AL, E). "Barış herhangi bir konu yüzünden tartışmamak, savaş hâlinde olmamak” (GL, B).

Hakvoort, Hagglund ve Oppenheimer'in (1998) yaptıkları çalışmada Hollandalı çocuklar, İsveçli çocuklara kıyasla daha fazla oranda barışı negatif barış olarak tanımlamıştır.

Öğrenciler üçüncü sırada (\% 12.7) barışı, savaşla ilgili düşüncelerle (Kategori 4) ifade etmiştir. Savaşla ilgili düşünceler evrensel ve kişisel olmak üzere iki alt boyuta ayrılmaktadır. Öğrencilerden kişisel düzeyde savaşla ilgili düşüncelerden 9 kez tekrar alınırken, evrensel düzeyde savaşla ilgili düşüncelerle ilgili 5 kez tekrar alınmıştır. 
"Silahların olmadığı, kan dökülmediği ortam” (IHHL, E). “ínsanlarin ve milletlerin savaşmaması"'(GL, B).

Öğrenciler dördüncü sırada (\% 10.9) barışı ayrımcılıkların olmadığ insan tutumlarıyla (Kategori 6) ilişkilendirmiş̧tir.

"Yok edilmeye çallşllan en önemli kavramlar: Kardeşçe ve rahat yaşamak" (IHL, B). "Kimsenin trkçı olmadı̆̆ bir dünya. Kapitalist sistemin olmadlğg ve her insanin birbirine insan olduğu için baktığl, yardım ettiği bir dünya olursa burada barış sağlanmış olur" (GL, B). "Insanların birbirlerine, ırk, din ayrımı yapmaksızın başkalarının haklarını sabote etmeksizin, huzur ve güven içinde yaşamasıdır" (GL, $B)$.

Hakvoort, Hagglund ve Oppenheimer (1998) yaptığı çalışmada ise Hollandalı çocuklar İsveçli çocuklara oranla daha fazla barışla insan tutumlarını ilişkilendirmiştir.

Öğrencilerin \% 10'u barışı kategori 2'de tanımlamıştır. Kategori 2 ise, üç alt boyuttan oluşmaktadır. Bu kategoriyle ilgili 11 kez tekrar yapılmıştır. Öğrenciler bu kategorinin 3 alt boyutundan 10 kez doğa, 1 kez ise din alt boyutuyla ilgili cevaplar vermiştir. Materyal alt boyutuna ise vurgu yapılmamıştır.

"Barış kelimesi bana beyaz güvercini, zeytin dalını hatırlatı" $(M L, B)$. "Barlş, güvercin ve zeytin dall" (FL, E). "Dinlerden bahsederim, İslâm”(IHL, B). 
Öğrencilerin \% 3.6'sı barışı, evrensel haklarla (Kategori 7) ilişkilendirdiği görülmüsşür.

"Evrensellik gelir aklıma” (GSSL, B). "Özgürlük olarak derim arkadaşıma" (GL, E).

Ortaöğretim öğrencileri barışı en az oranda ise \% 1.8 silahsızlanma (Kategori 5) ile ifade etmiş̧ir.

"Kanın dökülmediği, silahların ateşlenmediği ortam” (GL, E).

\section{Ülkenizde ve dünyada barış nasıl gerçekleşir?}

Araştırmanın bu sorusu öğrencilerin barışın nasıl olacağına, barışın nasıl yapılabileceğine ilişkin görüşlerinden oluşmaktadır. Bu soru ayrıca dünyanın ve Türkiye'nin nasıl barış dolu bir yer olabileceğine ilişkin öğrenci görüşlerini de içermektedir. Çalışma sorularıyla beraber sonda sorular da kullanılarak öğrencilerden cevaplar alınmış ve sonuçlar aşağıda belirtilmiştir. Bu bölümde verilen cevaplar yedi kategori ve alt boyutlardan oluşmaktadır. 


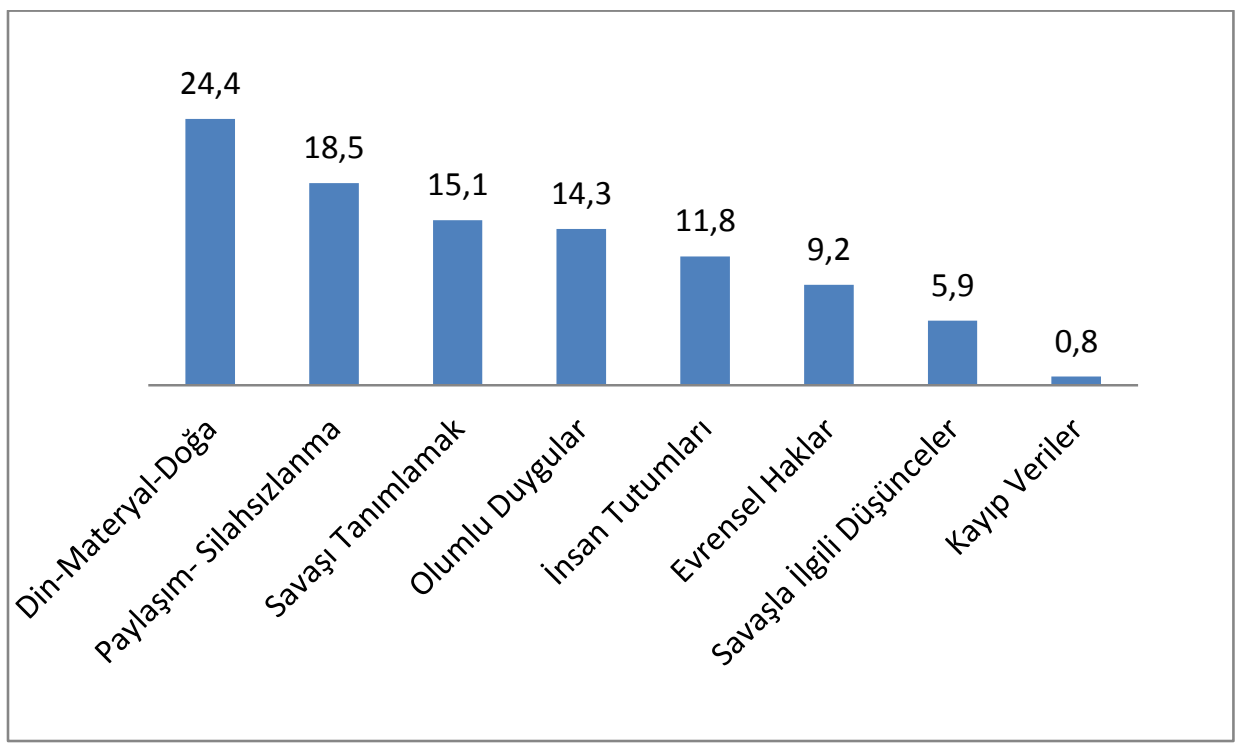

Grafik 2. Barış Nasıl Olur, Barış Nasıl Gerçekleşir Sorusuna Yönelik Cevaplar

Grafik 2'de görüldüğü gibi öğrencilere barış nasıl olur diye sorulduğunda Öğrenciler \% 24.4 oranında din-iletişim ve doğa alt boyutlarının yer aldığı kategori 2'de cevap vermiştir. Kategori 2'de toplam $30 \mathrm{kez}$ tekrar yapılmıştır. Bu cevapların $27 \mathrm{kez}$ tekrarı iletişim, 2 kez tekrarı din, $1 \mathrm{kez}$ tekrarı ise doğa alt boyutunda toplanmıştır. Ortaöğretim öğrencileri devlet yetkililerinin halk ile diyalog kurmasına özel bir önem vermektedir.

“Barış Allah'in nasibiyle olur, Allah nasip ederse olur (GL, E). "Savaş da barış da iletişimle başlar, dinlerden bahsederim, İslam”(IHH, B). "Halkın birlik ve beraberliğini vurgulardım. Kurtuluş Savaşı 'ndan bahsederdim. Televizyon programları hazırlatırdım, halka söylev yapılabilir” (ML, B). 
Öğrenciler ikinci sırada barışın olmasını kategori 5'e bağlamıştır. Kategori 5, silahsızlanma ve paylaşım olarak iki alt boyuttan oluşmaktadır. Bu kategoride $22 \mathrm{kez}$ tekrar yapıldı. 21 kez paylaşım $1 \mathrm{kez}$ ise silahsızlanma cevabı verilmiştir. Kategori 5 'te cevap veren öğrencilerin tamamına yakını paylaşım boyutunu seçmiştir. Türk halkının Somali'de açlık çeken insanlara yaptığı yardımlar Türk toplumundaki bu tutumun davranışa da yansıdığını göstermiştir.

“Türkiye'de herkesin kardeş olmasını sağlardım. Doğu ve Batı'yı kaynaştırırdım. Doğu'ya okul ve hastane açardım, ekonomik olarak kalkındırırdım. Cumhurbaşkanı ezilen tarafın yanında olmalı. ABD’nin sömürdüğ̈̈ ülkelere, Hindistan'a ve Endonezya'ya besin ve klyafet gönderirdim”(IHHL, E). “Dünya barlşı için kutllk çeken yerlere yiyecek gönderirim” (AL, E). “Insanî yardım yaparız, ilaç, yiyecek, Kızılay'la Afrika'ya yardım göndeririz, Afrika oldukça fakir" (GSSL, B). "Silahlanmayı engellerdim" (IHL, E).

Brezilya'da yapılan çalışmada Hakvoort, Hagglund ve Oppenheimer (1998, s.102) aynı kategoriyi seçen öğrenciler barış için fakir ülkelere yardımların yapılmasının gerektiğini düşünmektedir.

Porter (1926) tarafindan yapılan çalışmada "Silahlanma barışı garantiye almanın en iyi yoludur" şeklindeki önermeye öğrencilerin büyük bir bölümü kesinlikle yanlış kategorisinde cevap vermiştir. Porter'ın çalışmasında silahlanmanın hem kişisel hem de ulusal anlamda barışı tehdit ettiği sonucu ortaya çıkmıştır.

Ortaöğretim öğrencileri üçüncü sırada \% 15.1 oranında barışın 
olmasını savaşların yokluğu ile ilişkilendirmiştir.

"Barış için, önce iç savaşı kaldırmaya çalışırdım. Savaşın nedenini tespit ederim" (IHH, E).

Öğrenciler barışı dördüncü sırada (\% 11.8) barışın sağlanması ayrımcılığın olmadığı insan tutumları kategorisinde değerlendirmiştir.

“Din, dil, ırk ayrımcılıklarını kaldırırdım” (IHL, B).

Beşinci sırada ise (\% 9.2) barışın olmasını evrensel haklar ile açıklanmıştır.

"BM genel sekreteri olsam, dünyada adaletli seçimler yapardım” (SP, B). "Dünyanın lideri olsaydım savaş ekonomisine yatırım yapmaktansa insanlara yatırım yapmay tercih ederdim. Hizmet alanına yatırım yapardım. Herkesi yeteneklerine göre yönlendirirdim” (AL, E). “Antlaşmalar ve kurallar koydururdum, sözlü ve yazılı antlaşmalar"(IHH, B).

Öğrenciler en az oranda (\% 5.9) ise barışın olmasını savaşlarla ilgili düşüncelerle açıklamıştır.

Ülkeniz savaş yaşarsa ya da başka bir bölgede savaş olursa savaşı nasıl durdurursunuz? 


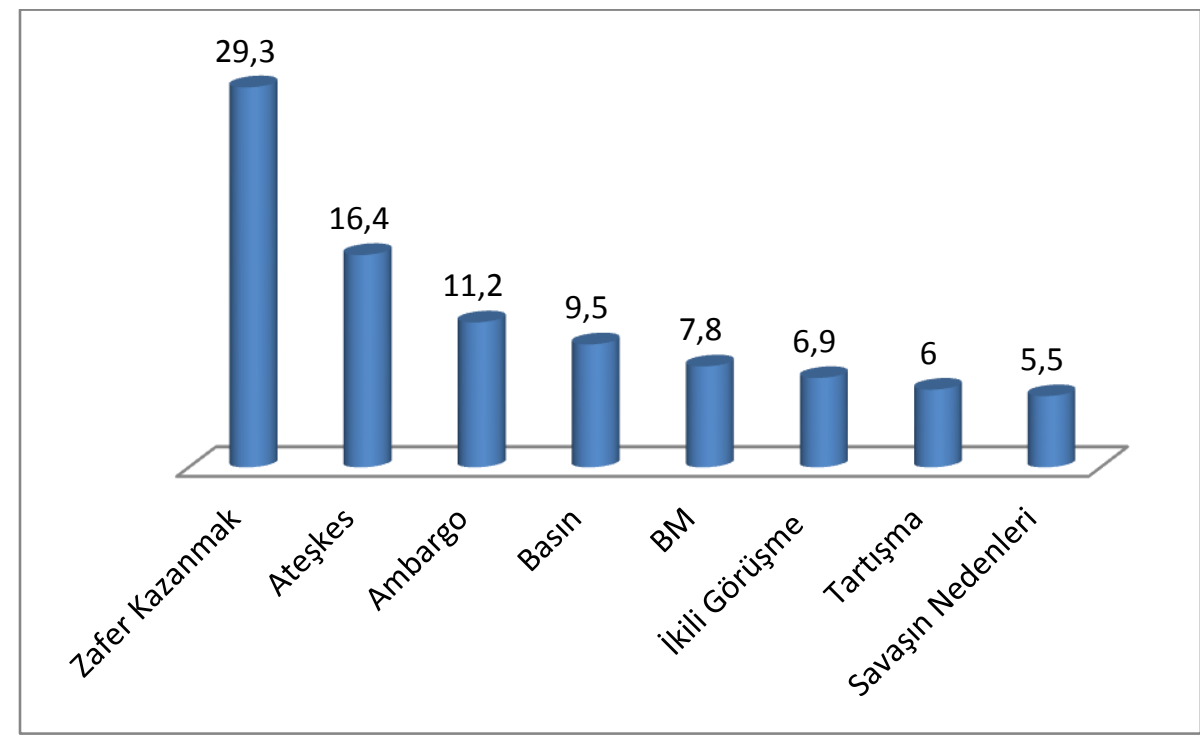

Grafik 3. Öğrencilerin Savaşların Önlenebilmesi ile İlgili Düşünceleri

Grafik 3'te belirtildiği gibi öğrencilere “Ülkeniz bir başka ülkeyle savaş yaşarsa ya da dünyadaki savaşları nasıl durdurursunuz" sorusuna öğrenciler geniş yelpazesi olan cevaplar verdiler. Öğrencilerden bu cevapları verirken devlet başkanının ya da BM genel başkanının yerine kendilerini koymaları istenmiştir.

Ortaöğretim öğrencileri \% 29.3 oranında “eğer ülkem başka bir ülke ile savaşırsa, savaşa devam edip onu yenerek barışı sağlayabilirim" (Kategori 8) cevabını vermiştir.

“Öncelikle çıkarıma bakarım, savaşı kazanacaksam savaşa devam ederim. Barışı sağlamaktan ise kaybım yoksa barışı sağlarım” $(\dot{I} H L, B)$.

İki ülke arasında savaş yaşanması durumunda iki ülkenin hakla- 
rını gözeterek bir anlaşma yapılmalı cevabını veren öğrencilerin oranı $\% 16.4$ olmuştur.

“Başka ülke ile savaş varsa iki ülkenin istediği gerekli şartları yerine getiririm” (GSSL, E). "Ülkem başka ülkeyle savaşırsa uzlaşma yollarını arardım” (GL, B).

Öğrenciler üçüncü sırada (\% 11.2) ise zayıf ülkeye destek; savaş yapan ülkeye ambargo uygulanmalı kategorisini tercih etmiştir.

"Yenilen tarafa silah yardımı yapılabilir, yenen ülkeye silah ambargosu” (FL, E). “Düşük olan ülkeleri sömürgeme alırdım. Sömürge derken güvenceye alırdım, güçsüz ülkelere asker gönderirdim”, (GL, B).

Öğrenciler basın ve yayın yoluyla diğger liderle görüşme seçeneğini (Kategori 3) \% 9.5 oranında tercih etmiştir.

"Dünya için diktatör liderleri uyarırdım, liderlere mektup yazardım" (IHL, E).

Öğrencilerin 4,3'ü savaş durmalı (Kategori 1) gibi genel ifadeler kullanmış; ama sorunun çözümüne yönelik bir somut öneride bulunmamıştır.

Diğer ülkeyle ya da lideriyle bizimle savaşa son vermesi için ikili görüşme ya da toplantı yapmak (Kategori 5) önerisi \% 6.9 oranına denk gelmiştir. 
"Anlaşmazlıkları ortadan kaldırırdım, insanları olumlu etkilerim konuşarak, huzur ve barışın gerekli olduğunu söylerim” (GL, B).

Savaşın nedenini bulmaya çalışmak, savaşa gerek olmadığına dâir fikirlere sahip çıkmak (Kategori 6), \% 5.2 oranına denk gelmiştir.

"İlk önce savaşın sebebini ögrrenir ve çözerim, hammadde ve petrol savaşın nedeni olabilir, o mağdur kişilerle konuşurum” (GSSL, B).

Öğrenciler, tartışma ve kalıcı antlaşmalar yapma seçeneğini (Kategori 7) \% 5.2 oranında tercih etmiştir.

"Antlaşmalar ve kurallar koydururdum. Sözlü ve yazılı anlaşmalar” (GL, B). “Mustafa Kemal Atatürk'ün yolunda, onun sözü ışlğında "Yurtta sulh, cihanda sulh" barışı sağlamaya çalışırdım. Antlaşmalarla garanti eder, çıkar gözetmemeye özen gösterirdim. "Savaş yoluyla değil, antlaşmalar ya da farklı yöntem kullanırdım” (GL, B). “Antlaşmalar yapardım, aydınlarla konuşurdum” (ML, B).

Öğrenciler BM'ye başvurma seçeneğini (Kategori 9) ise \% 7.8 oranında tercih etmiştir.

“Başka bir ülkeyle savaşırsa, mezhep farklarını ortadan kaldırırdım, kendim bir şey yapmaya hazırlanırdım. Etraftaki güçlerden yardım isterdim. Arabulucu da arardım. Barış istiyorsam destek değil ara bulucu isterdim" (IHL, E). "BM genel sekreteri olsaydım, her ülkenin kendi sorunlarını dinlerdim, karşı ülkelerden ne beklediklerini 
ögrenirdim. Ara buluculuk yapardım” (GL, B).

Ortaöğretim öğrencileri en az oranda (\% 3.4) savaş yapan ülke liderine ceza verme kategorisiyle ilgili cevap vermiştir.

"Savaş yapan ülkenin liderini zorla görevden alırdım" (GSSL, E). "Savaş yapan insanları hapse atardım” (GL, E).

\section{Dünyada barış var mı?}

Öğrencilere dünyada barışın olup olmadığı konusunda düşünceleri sorulmuştur. Bu soruya verilen cevaplar dört kategoride toplanmıştır. Öğrencilerin verdikleri cevapların yüzdelik oranları ve örencilerin verdikleri cevaplar aşağıda ifade edilmiştir.

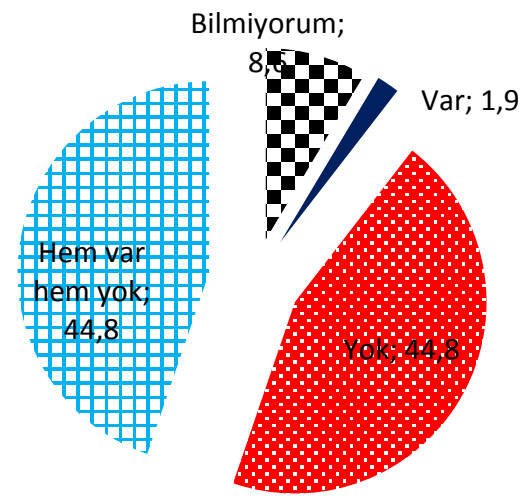

Grafik 4. Öğrencilerin Dünyada Barışın Olup Olmadığına Dâir Fikirleri

Grafik 4'ten anlaşılacağı gibi öğrenciler dünyada barış var mı sorusuna \% 44.8 oranında dünyada barış yok kategorisinde cevap vermiştir. 
Hayır, dünyada maden kaynaklarına ihtiyaç var, gelişmiş ülkeler her gelişmemiş ülkelerin kaynaklarını kullanıyorlar (GSSL,E). “Dünyada barış yok, herkes birbirini sömürmeye çalışıyor (GSSL, B). “Dünyada barış yok çünkü ABD gibi sömürgeci bir devlet var”( $M L, B)$.

Öğrenciler \% 44.8 oranında dünyanın bazı bölgelerinde barış var bazı bölgelerde barıș yok cevabını vermiştir.

"Dünyada barış hem var hem yok" (FL, E).

Öğrencilerin \% 8.6'sı ise ya bilmediklerini söylemiş ya da ilgisiz cevaplar vermiştir.

“Dünyada, bilmiyorum” (İHL, B).

Cairns, McLernon, Moore ve Hakvoort (2007) Kuzey İrlanda'da 1994 yılında imzalanan ateşkes anlaşması öncesinde ateşkes sonrasında ve 2002 yılında öğrencilerle çalışma yapmışlardır. Araştırmacılar çocuklara "Ülkenizde savaş mı yoksa barış mı var?" sorusunu yöneltmişlerdir. Ateşkes anlaşması öğrencilerin görüşlerinde olumlu değişime yol açmıştır. Yani öğrencilerden ülkemizde savaş var diyen öğrenci sayısında azalma olmuştur. Ülkemizde barış var diyen öğrenci sayısında ise artış olmuştur. Fakat 2002 yılına gelindiğinde belirsizlik ortamı oluşmuştur. Yani barış imzalandıktan sonra umut ortamı yaratmasına rağmen bu durum zaman geçtikçe yerini karamsarlığa b1rakmıştır.

Ortaöğretim öğrencilerinin sadece \% 1.9'luk kısmı ise dünyada 
barış var kategorisini tercih etmiştir. Bu bulgular öğrencilerin barış konusunda kötümser bir görüşe sahip olduklarını göstermiştir.

Köhber Vakfi'nın lise birinci sınıf öğrencileriyle yaptı̆̆ 1 araştırmada Kuzey Avrupalı gençlerde barış konusunda düşük oranda bir gerileme beklentisi vardır. Eski Sosyalist Blok ülkelerindeyse Rusya ve Bulgaristan dışında ülkenin barış dolu bir geleceğe gittiği hakkında gelişme beklenmektedir. En yüksek gelişme bekleyen ülkeler Litvanya, Çek Cumhuriyeti, İsrail'dir. Bu araştırmada ülkenin kırk yıl önceki ve kırk yıl sonraki zaman diliminde ülkenin barışçı bir geleceğe doğru ilerlemesi hakkında en olumlu beklenti Türk öğrenciler arasındadır (Tekeli, 1998, s.58). Yani araştırmalarda Türk öğrenciler dünya bar1şıyla ilgili kötümser bir görüşe sahipken, Türkiye ile ilgili olumlu görüşe sahip oldukları sonucu ortaya çıkmıştır.

Türkiye'nin barış dolu bir yer olması için kim katkı sağlamaktadır?

Öğrencilere Türkiye'de olan barış ortamına hangi insanların ya da kurumların katkı sağladığı sorusu sorulmuştur. Bu bölüme verilen cevaplar yedi kategoride toplanmıştır. Öğrencilerin verdikleri cevapların yüzdelik oranları ve kategorilere verdikleri cevaplara ilişkin örnekler aşağıda ifade edilmiştir. 


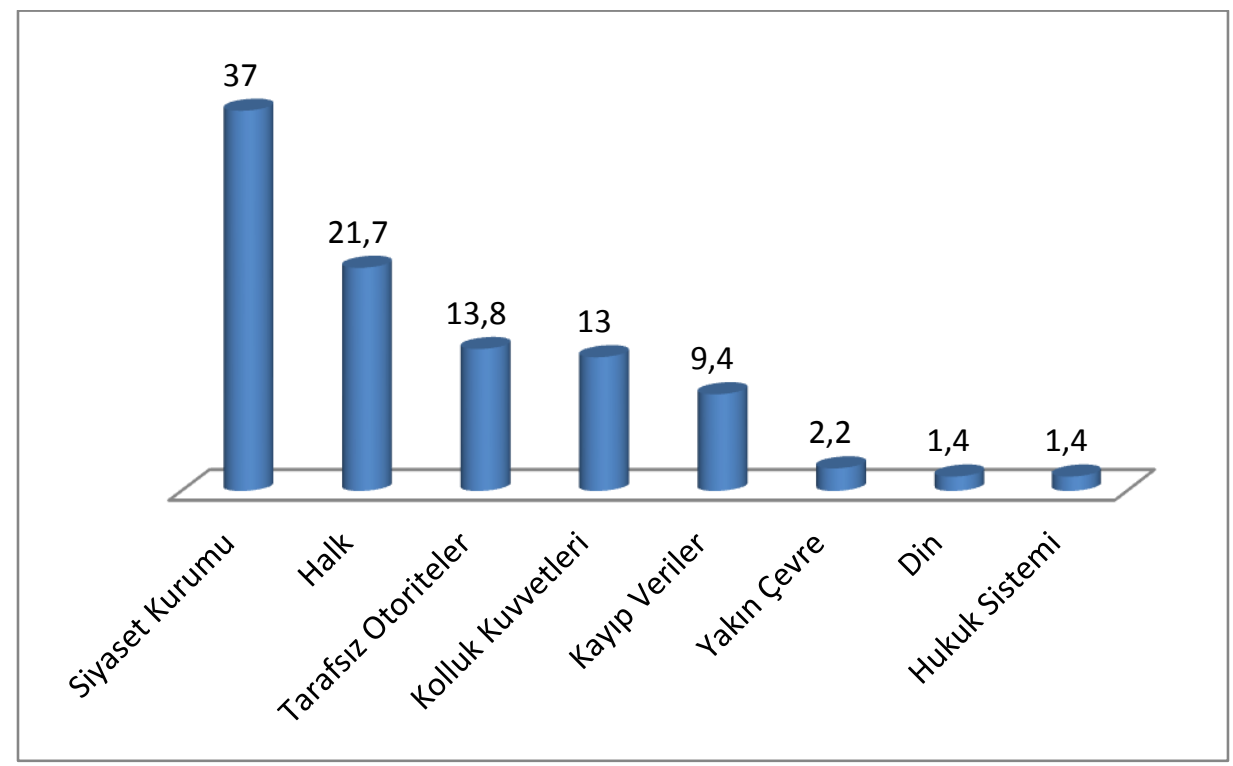

Grafik 5. Öğrencilerin Türkiye'de Barışa Kimin Katkı Sağladığına Dâir Görüşleri

Öğrencilere, Türkiye'nin iç barışına katkı sağlayan kim? diye sorulmuştur. Grafik 5 'teki verilerden anlaşılacağı gibi öğrenciler ilk sırada (\% 37) siyaset kurumunun barışa katkı sağladığını söylemiştir.

"Türkiye'de başbakan ve cumhurbaşkanı katkı sağllyor" (SBL, E). "Siyasi parti liderleri katku sağllyor" (AAL, E). "Başbakan, cumhurbaşkanı, milletvekilleri” (ML, B).

Wagner'e göre dünya barışına katk1 yapabilecek en büyük aktörler arasında politikacılar vardır. Politikacılar eğitim programlarına barış değerinin yerleştirilmesine katkı sağlayabilir, nükleer savaşların yaşanmaması için uluslararası politikada yapıcı rol oynayabilir (Wagner, 1988, s.8). 
Öğrenciler ikinci sırada, \% 21 oranında halkın kendisi Türkiye’de barışa katkı sağlıyor cevabını vermiştir.

“Halkın kendisi” (GL, E). “Insanlar, Türkiye'nin kendi halkl” (AL, B).

Öğrenciler üçüncü sırada (\% 13.8) tarafsız otorite Türkiye'de barışa katkı sağlar cevabını vermiştir.

“Insanlar sayesinde olur. Herkesin düşüncesine saygılı olmalıyız. Aydınlar ve fikirleri çok önemli bence. Namık Kemal ve Mehmet Âkif sayesinde olmuştur” (ML, B). "Volkan Konak, bu adamdan başka ülkede barlşı savunan ve sağlayan kimse yok” (GL, B). "Türkiye'de barışa katkı sağlayanlar: Halkın içindeki bazı aydın kesimler, yazarlar ve gazeteciler barış yolunda katkıda bulunuyorlar" (GL, B). "Dünya için çal, sanatçı grupları" (GSSL, B).

Öğrenciler dördüncü sırada da (\% 13) kolluk kuvvetleri Türkiye'de barışa katkı sağlıyor cevaplarını vermiştir.

“Türkiye'nin barış dolu bir yer olmasını sağlayan ilk kişi Atatürk'tür. Ve şimdiye kadar onun gibi ülkesine katkıda bulunan kimse olmamıştır. Tabii ki Atatürk'e destek veren canını hiçe sayan silah arkadaşları. Şu ânki sınırı bekleyen askerlerimiz vb. dışında, bu ülkeyi savunmaya çalışanların dışında”(GL, B). "Huzur ortamını insanlar, yasalar, polisler, anayasa, mahkemeler” (ML, B). “Asker ve polis katkı să̆llyor” (IHH, B). 
Öğrenciler beşinci sırada ise (\% 9.4) ya geçerli bir cevap vermemiş ya da Türkiye'de barışa kimsenin katkı sağlamadığını belirtmişlerdir.

“Türkiye'nin barlş dolu bir yer olduğunu düşünmüyorum, bu durumda katkı sağlayan yoktur” (GL, B). "Barış dolu bir yer olması için herkesin katkısı olması lazım. Terör yüzünden her ay onlarca kişi ölüyor sadece bizim bildiğimiz. Bu nedenle bizim ülkemizde barış yok ve olması için hiçbir şey yapılmıyor” (GL, B).

Öğrenciler barışa katkı sağlayanlar olarak kendi annem babam ya da öğretmenlerim yani yakın çevre kategorisine ise \% 2.2 oranında cevap vermişlerdir.

"Aile reisi, baba, arkadaşlar arasında herkesin kendisi (GSSL, B). “Öğretmenlerimiz” (GSSL, E).

Ortaöğretim öğrencileri en az oranda ise (\% 1.4) hukuk sisteminin Türkiye'nin barışına katkı sağladığını dile getirmişlerdir.

"Huzur ortamını insanlar, yasalar, polisler, anayasa, mahkemeler" (ML, B).

Hakvoort'un (1996) 14-17 yaş arasındaki çocuklarla yaptığg çalışmada öğrenciler Hollanda'da barışa ilk sırada halkın kendisinin, ikinci sırada da hükümetin katkı sağladığını belirtmişlerdir.

Souza, Sperb ve McCarty (2006) tarafından yapılan çalışmada öğrenciler barışın sağlanmasında en yüksek oranda din ögesinin etkili 
olduğunu belirtmişlerdir. Brezilyalı öğrenciler ikinci sırada ise en yüksek oranda halkın kendisinin barışa katkı sağladığını dile getirmişlerdir. Öğrencilerin Türkiye'de barışın sağlanmasında siyaset kurumunu tercih etmesi öğrencilerin sorunları demokrasiyle çözeceğine işaret etmektedir. Köhber Vakfı'nın yaptığı araştırmada öğrencilerden ülkelerinin kırk yıl öncesi ve kırk yıl sonrası zaman dilimini değerlendirmeleri istendiğinde Türkiye'deki lise birinci sınıfta eğitim gören öğrenciler demokrasinin gelişme kaydedeceği hakkında iyimser bir görüş belirtmişlerdir (Tekeli, 1998, s.200). Türkiye'de gençlerin, demokrasinin gelişimine yönelik umutlu oldukları her iki çalışmanın sonuçlarından da anlaşılmaktadır.

Türkiye barışa katkı sağlamak için hangi coğrafyalara asker göndermiştir?

Öğrencilere, Türkiye'nin barışa katkı sağlamak amacıyla hangi bölgelere asker gönderdiğiyle ilgili sorular sorulmuştur. Öğrenciler yedi bölge ismi vermiştir. Öğrencilerin verdikleri cevapların yüzdelik oranı aşağıda belirtilmiştir. 


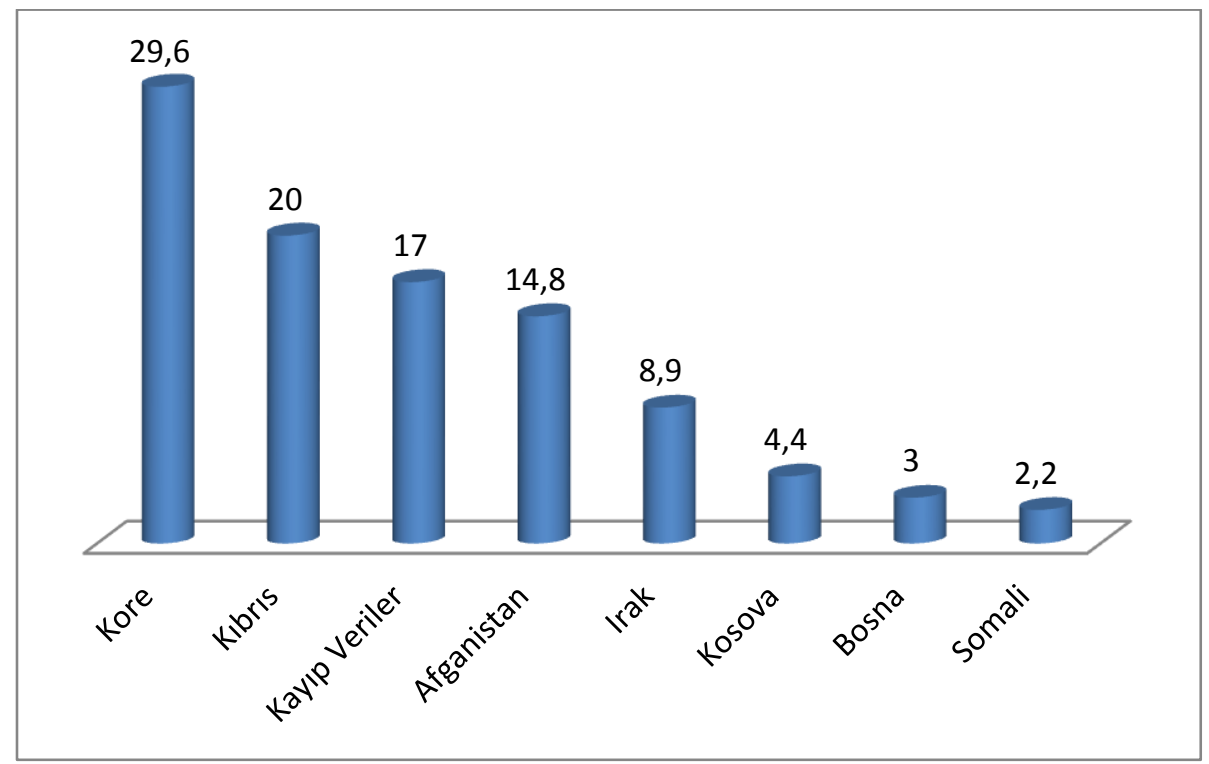

Grafik 6. Öğrencilerin Türkiye'nin Barışa Katkı Sağlamak İçin Asker Gönderdiği Bölgelerle İlgili Cevapları

Grafik 6 incelendiğinde Türkiye'nin dünyanın hangi bölgesine asker gönderdiğiyle ilgili soruya öğrencilerin \% 29.6's1 Kore Savaş1 cevabını vermiştir. Öğrencilerin \% 17'si ise bu soruyu bilemediklerini ifade etmiş ya da anlamsız cevaplar vermiştir.

"Hatırlamıyorum, nereye asker gitti? (IHL, E). "Komşu ülkelere göndermişlerdir” $(G L, B)$.

Öğrencilerin ikinci sırada bildikleri Kıbrıs Barış Harekâtıdır. Öğrenciler üçüncü sırada (\% 14.8) Afganistan'a asker gönderildiğini söylemişlerdir. Öğrenciler \% 8.9 oranında ise Irak'a asker gönderildiğini ifade etmiştir. Öğrenciler \% 4.4 oranında Kosova, \% 3 oranında Bosna ve \% 2.2 oranında Somali'ye Türkiye'nin barışı korumak için 
asker gönderdiği cevabını vermişlerdir.

Eğer bir arkadaşınız sizin için önemli olan bir eşyayı aldı ve geri vermek istemiyorsa ne yaparsını?

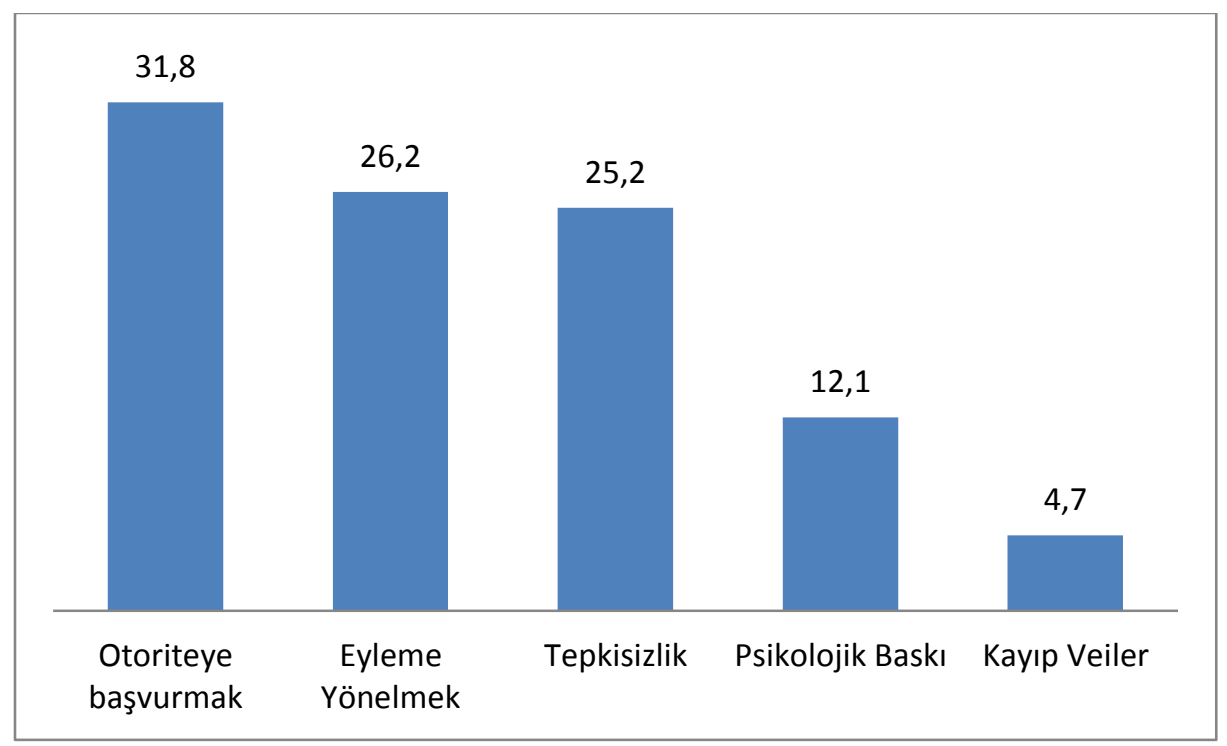

Grafik 7. Öğrencilerin Kendileri İçin Değerli Bir Eşyalarının Habersiz Alındığı Zaman Gösterebilecekleri Tutum ve Davranışlar

Öğrencilere "Eğer sizin için değerli olan bir eşyayı arkadaşınız ald1 ve size geri vermek istemezse sorunu nasıl çözersiniz?” sorusu sorulmuştur. Görüşmede sınıf öğretmeninin ya da danışmanlık yapan öğretmenin böyle sorunlar duymak istemediği de eklenmiştir.

Ortaöğretim öğrencileri en fazla oranda (\% 31.8) sorunun çözüme kavuşması için bir otoriteden yardım isteyeceklerini belirtmişlerdir.

“Vermezse ögretmenlere söylerim”(FL, E). 
Öğrenciler ikinci sırada (\% 26.2) eylemlere yöneleceklerini dile getirmişlerdir.

"Sinirlenirdim, ben de onun eşyasını alırdım” (GL, E). "Herkesin içinde rezil ederdim" (GL, E).

Ortaöğretim öğrencileri üçüncü sırada ise \% 25.2 oranında tepkisiz kalacaklarını dile getirmişlerdir.

"Eşya arkadaşımda kalsın derim” (GL, E).

Bu kategoride en az (\% 12.1) oranında ise "psikolojik baskı kurarım" cevabı alınmıştır.

"Araya mesafe koyar, konuşmazdım. Zorla eşyamı geri almaya çalışmam” (GL, B). "Sevdiğim arkadaşımsa veririm, yoksa vermem. Arkadaşım anlamazsa küserim kavga etmem" (IHL, E). "Çok iyi laf sokarım, vicdan azabına sokardim, dişlardim" (IHL, B).

Hakvoort ve Oppenheimer'in (1993) 6-18 yaş arasında yaşları değişen çocuklarla yaptığı çalışmada öğrencilerin yaşları küçüldükçe "bir otoriteye başvururum" seçeneğinin arttığı görülmüştür. Yine bu çalışmada yaşları büyük çocuklar ise genellikle gerçek bir arkadaş böyle bir şey yapmaz cevabını vermiştir. Hakvoort'un çalışmasına göre kız öğrenciler psikolojik baskıya başvurma kategorisine erkeklere oranla daha fazla başvurmaktadır. 


\section{İki ülkenin savaştığını düşünün. Her iki ülke de barış için} karşı tarafın adım atmasını istiyor, sizce barış için ilk adımı hangi devlet atmalı?

Ortaöğretim öğrencilerine savaşta olan iki devletin barış için ilk adım atması gerektiğinde hangi devletin ilk adımı atması gerektiği sorulmuştur. Öğrencilerin verdikleri cevaplar yedi kategoride toplanmıştır. Öğrencilerin kategorilere verdikleri yüzdelik oranlar ve örnekler aşağıda ifade edilmiştir.

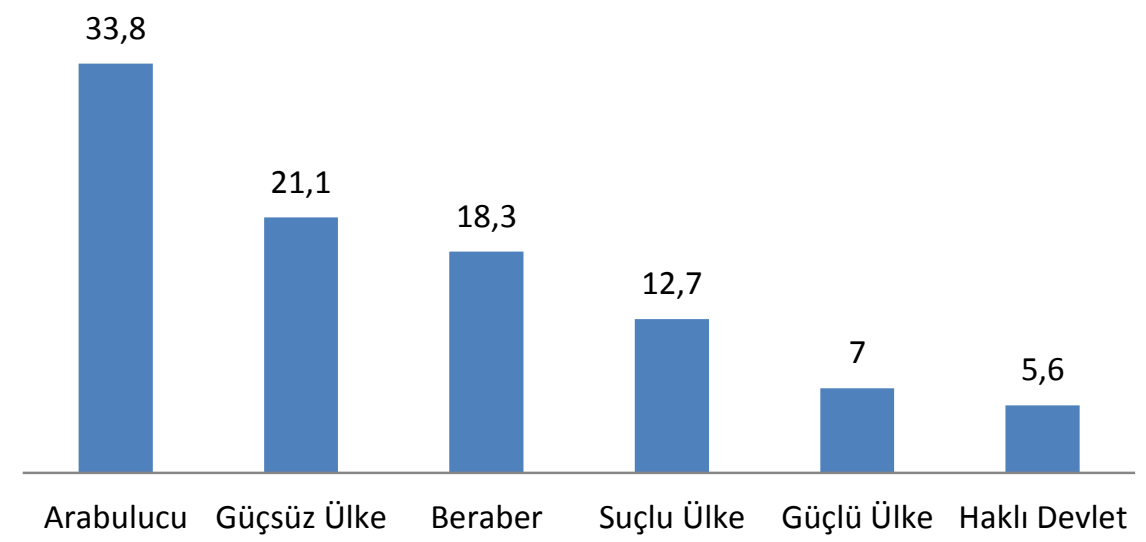

Grafik 8. Savaş Yapan İki Ülkeden Hangisinin Barış İçin İlk Adımı Atması Gerektiğine Dair Öğrenci Görüşleri

Grafik 8 incelendiğinde ortaöğretim öğrencileri savaş yapan iki ülkenin barış yapabilmesinde ara bulucu bir ülkenin olmasını önemsemişlerdir. Bu kategori \% 33.8'le en fazla oranda tercih edilmiştir.

“Aracı bir devlet olmalı” (IHHL, E). “Üçüncü bir ülke adım atmalı" (GL, B). İki devlet görüşmeye karar veremiyorsa bir ara bulucu 
olmalıdır" (ïHL, B).

On yedinci yüzyılda yaşamış, savaş ve barış hukukunu değerlendiren Hugo Grotius savaşın hakemlikle de önlenebileceğini savunmuştur (Grotius, 2011, s.206).

Ortaöğretim öğrencileri, ikinci sırada da güçsüz ülkenin barış için ilk adımı atması gerektiğini söylediler. Çünkü savaş devam ederse güçsüz ülkenin daha fazla zarar göreceği düşünülmüştür.

“Barış için zayıf ülke ilk adımı atmalı” (FL, E).

Öğrencilerden (\% 18.7) "iki devlet barış görüşmesine aynı anda başlasın” cevabı üçüncü sırada alınmıştır.

"İkisi de aynı anda adım atmalı" (ML, B)

Öğrenciler dördüncü sırada ise (\% 12.7) suçlu ülke adım atmalı cevabını vermiştir.

"Barış için ilk adımı suçlu olan ülke atmalı" (AL, E). "Suçlu devlet ilk adımı atmalıdır “ (IHL, E).

Öğrenciler \% 7 oranında “güçlü devlet ilk adımı atmalı” cevabını vermişlerdir.

“Güçlü olan devlet başlamalı” (ML, B).

Hugo Grotius (2011) barış görüşmesine başlamada yenen tarafin ilk adımı atmasının önemine dikkat çekmiştir: Grotius'a göre "Çünkü 
işlerimizin iyi gittiği bir sırada barış yapmak istersek, ünümüze ve şanımıza daha yaraşır bir davranışta bulunmuş oluruz. Böyle bir barış, umutla beklenilen bir zaferden daha değerli olduğu gibi, daha çok güvenlik sağlamaktadır."

Öğrenciler en az oranda ise (\% 5.6) haklı devletin barış görüşmesi için ilk adımı atması gerektiğini dile getirmiştir.

"Haklı devlet ilk adımı atmalıdır" (IHHL, E). "Haklı olan ülke atmalıdır" (GSSL, E).

\section{Savaş nedir, savaş kelimesi size neyi hatırlatır?}

Öğrencilerden savaşı tanımlamaları istenmiştir. Öğrencilerin savaşın tanımına ilişkin görüşleri dokuz kategoride toplanmıştır. Öğrencilerin savaşın tanımı kategorilerine verdikleri cevapların yüzdelik oranları ve kategorilere verdikleri örnek cümleler aşağıda verilmiştir.

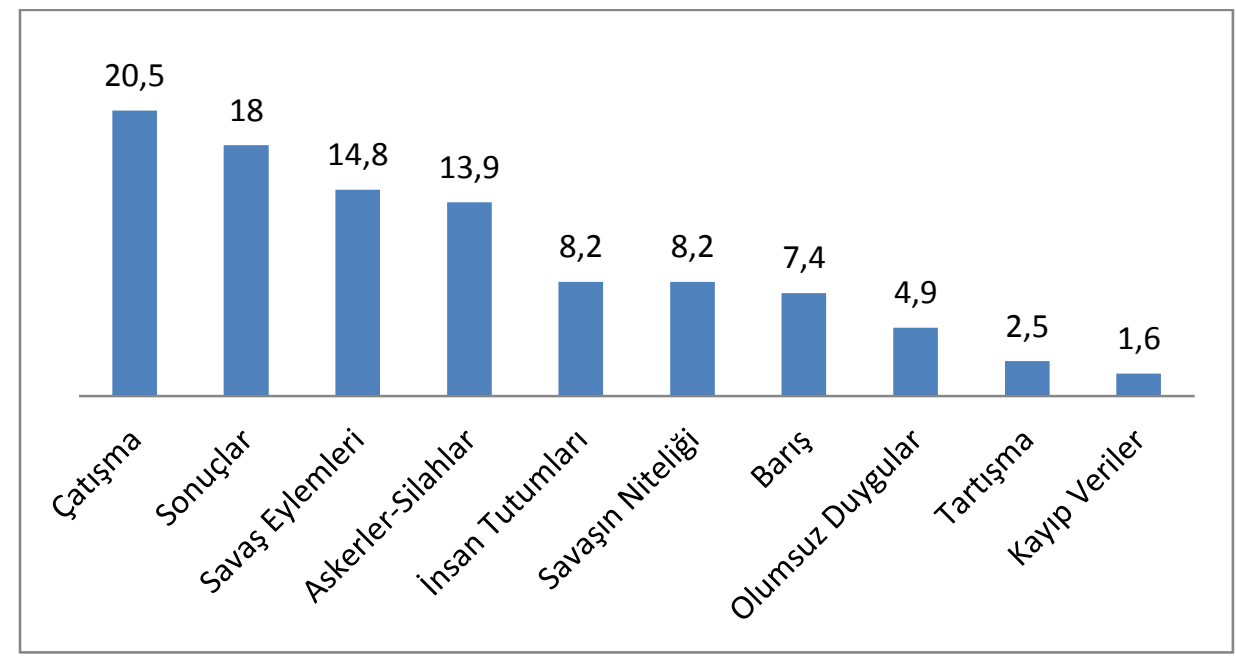

Grafik 9. Öğrencilerin Savaşa İlişkin Tanımları 
Grafik 9 değerlendirildiğinde öğrenciler en fazla oranda (\% 20.5) savaşı çatışma ile tanımlamışlardır.

"Sorunların, iki taraftan birinin klşkırtmasıyla ya da iki taraftan birinin ülke egemenliğini, millet şerefini zedeleyecek tavırları karşı tarafin da göstermesi sonucu ortaya çıkan çatışma” (GL, B).

Öğrenciler ikinci sırada ise savaşı, savaşın sonuçlarıyla tanımlamıştır;

"Savaş: Kan dökülmesidir. Suçsuz insanların hayatını kaybetmesidir” (GL, B). “Savaş, acı, ölüm, çocuk feryatlarl, anne feryadı, çok kötü bir şey, herkesin canının yandiğgl, suçlunun ve suçsuzun da ölmesidir (GL, B). “İnsanların bă̆ımsızlıklarının kaybolmasıdır” (İHL, E). “İnsanların ölümü, ekonomik yıpranma” (IHHL, E). “Öldürülen insanlar, çocuklar..." (ML, B).

Öğrenciler üçüncü sırada ise 14.8 oranında savaşı savaş aktiviteleriyle (Kategori 4) tanımlamıştır.

“ikki ülkenin anlaşmazlı̆̆ının şiddete dönüşmesi” (GL, E).

“Topla, tüfekle olan tartışma” (AL, B). "Elinde silahlart ve blçakları olan insanların çatışması" (ML, B).

Öğrenciler askerler-silahlar kategorisini \% 13.9 oranında tanımlamıştır.

“Savaş görüntüsü, kurşunlar, tanklar” (AL, E). "Silahlar, sesler, 
toplar, gürültü" (SPL, B). “Kan, silah” $(F L, E)$.

Hakvoort, Hagglund ve Oppenheimer'1n (1998) yaptıkları çalışmalarda ise İsveç ve Hollandalı yetişkin çocuklar (11-13 yaş) savaşı en fazla oranda kategori 2 yani askerler-silahlar kategorisinde cevaplandırmıştır.

Ortaöğretim öğrencileri dördüncü sıradaysa (\% 8.2) savaşı, insan tutumlarıyla (Kategori 5) tanımlamışlardır.

"Savaş, insanların birbirlerine dayanamadıklarl, birbirlerinin haklarına göz diktikleri, sabote etmek istediklerinde gerçekleşir. Birbirlerinin arasında ırk, dil, din ayrımı gördüklerinde meydana gelir" (GL, B). "Savaş insanların kötülük etmek için yaptıkları gereksiz şey” $(G L, B)$.

Ortaöğretim öğrencileri \% 8.2'lik oranda savaşı, savaşın niteliği (Kategori 9) ile tanımlamıştır.

“Insanlar veya devletlerin arasındaki görüş ayrılıkları, anlaşmazlıkların olmasıyla ortaya çıkan, sadece askeri değil, ulusu da yakıp kavuran en büyük kayıptır” (GL, B).

Savaşı barış ile ilişkilendiren (Kategori 1) öğrencilerin oranı ise $\% 7.4$ olmuştur.

"Savaşı, barışın olmadı̆̆ı ortam olarak tanımlarım. Savaş kelimesini duyunca, mutsuzluk, huzursuzluk, içimi kaplyyor” (GL, B). 
Öğrenciler \% 4.9 oranında olumsuz duygularla (Kategori 7) ilişkilendirmiştir.

“Huzursuzluk ve renk olarak siyah” (FL, E). “iki insan arasindaki ve iki toplum arasındaki huzursuzluk" (IHL, E).

Savaş1, tartışmayla (Kategori 3) ilişkilendirenler \% 2.5 oranında olmuştur.

"Fikir tartışması ve kavga" (FL, E).

Ortadoğu'da bir ülkede 15 yaşında Musa adında bir çocuk olduğunu hayal edin. Ülkenin savaşta askere ihtiyacı var; fakat çocukların savaşa katılmasını kimse istemiyor. Eğer karar Musa'ya bırakılırsa Musa ne yapmalı?

Araştırmanın bu sorusu öğrencilerin 15 yaşında olan bir çocuğun ülkesinin savaşta olması durumunda ne yapması gerektiğine ilişkindir. Öğrencilerin verdikleri cevaplar üç kategoride toplanmıştır. Kategorilerin yüzdelik oranları ve öğrencilerin verdikleri cevaplara ilişkin örnekler aşağıda verilmiştir. 


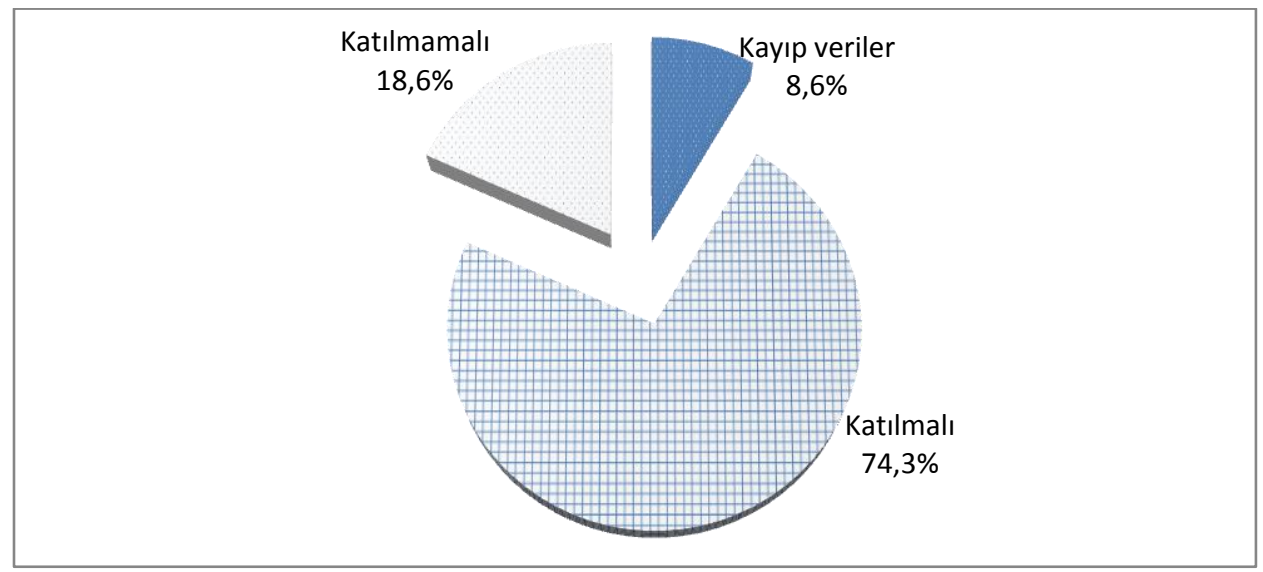

Grafik 10. Ülkesi Savaşta Olan 15 Yaşındaki Musa Adlı Çocuğun Savaşa Gidip Gitmeme Konusunda, Öğrencilere Göre Göstermesi Gereken Tutum ve Davranışlar

Grafik 10 incelendiğinde çalışmaya katılan öğrencilerin \% 74.3’ü vatan savunmasının kutsal bir faaliyet olduğunu, bu nedenle çocuk da olsa insanların vatanları için savaşa gitmeleri gerektiğini belirtmiştir.

"Musa savaşa katılmalı, vatanını korumak için katılmalı" (SBL, B). “Musa savaşa katılmalı. Ben olsaydım katılırdım. Sonuçta ülkesi onun, ülkesi kaybederse olan yine ona olacak, sonuçta toprak önemli" $(M L, B)$.

Öğrencilerin \% 18.6's1 gitmemesi gerektiğini dile getirmiştir.

"Musa savaşa katılmamall, on sekiz yaşında olsa da katılmamalı en az 25 yaşında olmalı, Zorla gitmemeli" (IHL, E). "15 yaşındaki çocuğun savaşta fayda vereceğini düşünmüyorum” (GSSL, B).

Öğrencilerin \% 8.6'sı ise ilgisiz cevaplar vermiş ya da cevap 
vermemiştir.

“Musa Müslümansa şehit olacă̆ını bilir, Müslüman’sa gözünü kırpmadan savaşa gider. Müslüman değilse zor” (IHL, E).

\section{Siz Musa'nın yerinde olsaydınız savaşa katılır mıydınız?}

Araştırmanın bu sorusunda öğrencilerin ülkesi savaşta olan $\mathrm{Mu}$ sa'nın yerine kendilerini koymaları istenmiştir. Bu soruya verilen cevaplar üç kategoride toplanmıştır. Öğrencilerin kategorilere verdikleri cevapların yüzdelik oranları ve cevaplara ilişkin örnekler aşağıda belirtilmiştir.

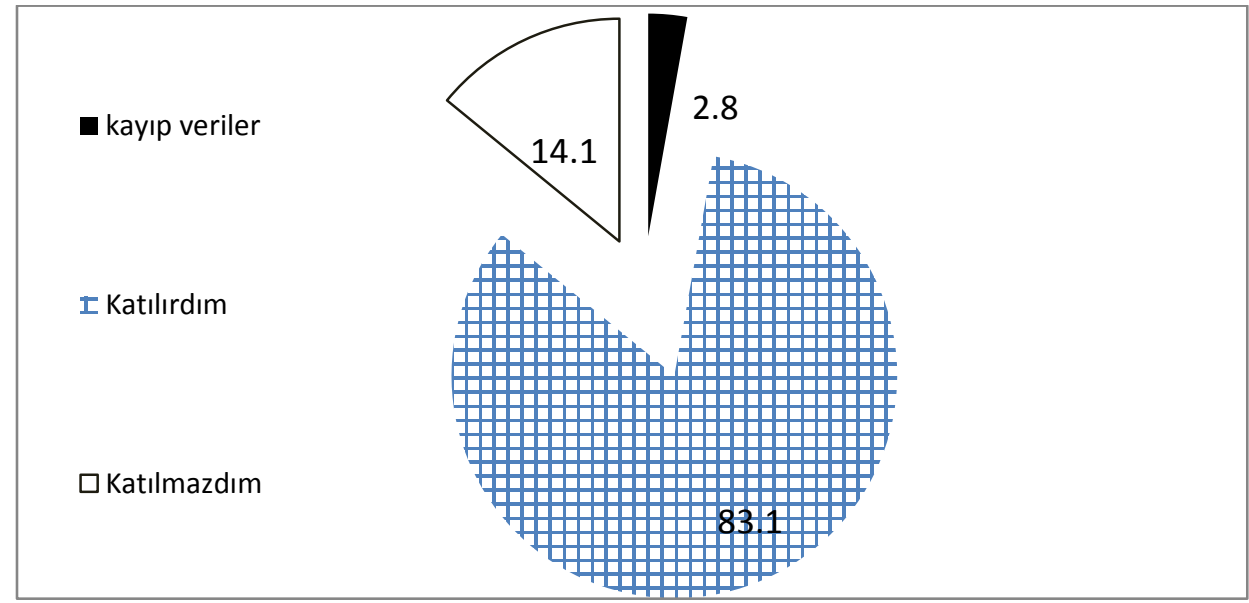

Grafik 11. Öğrencilerin Ülkesi Savaşta Olan 15 Yaşındaki Bir Çocuğun Yerine Kendilerini Koyarak Gösterebilecekleri Tutum ve Davranışlar

Grafik 11'de görüldüğü gibi “Siz Musa'nın yerinde olsaydınız savaşa gider miydiniz?" sorusuna öğrencilerin \% 83.1'i "giderdim" demiştir. Bu bulgular da öğrencilerin ülke savunmasına özel bir önem 
verdikleri sonucunu ortaya koymuştur.

"Musa savaşa katılmalı, ben olsam da katılırdım” (SBL, E).

Ortaöğretim öğrencilerinden "15 yaşında olsaydım savaşa gitmezdim" cevabını verenlerin oranı \% 14.1 olmuştur.

"15 yaş daha çocuk, bu yaşta katılmamall, ben 15 yaşında olsam katılırdım; çünkü bu benim Türk olmamdan kaynaklanıyor” (GSSL, E).

\section{5 yaşındaki bir çocuk neden savaşa gitmek istemeyebilir?}

"15 yaşındaki bir çocuğun neden savaşa gitmek istemeyebileceği” sorusuna öğrencilerden cevaplar alınmıştır. Öğrencilerin verdikleri cevaplar altı kategoride toplanmıştır. Öğrencilerin kategorilere verdikleri yüzdelik oranlar ve cevaplarla ilgili örnekler aşağıda belirtilmiştir.

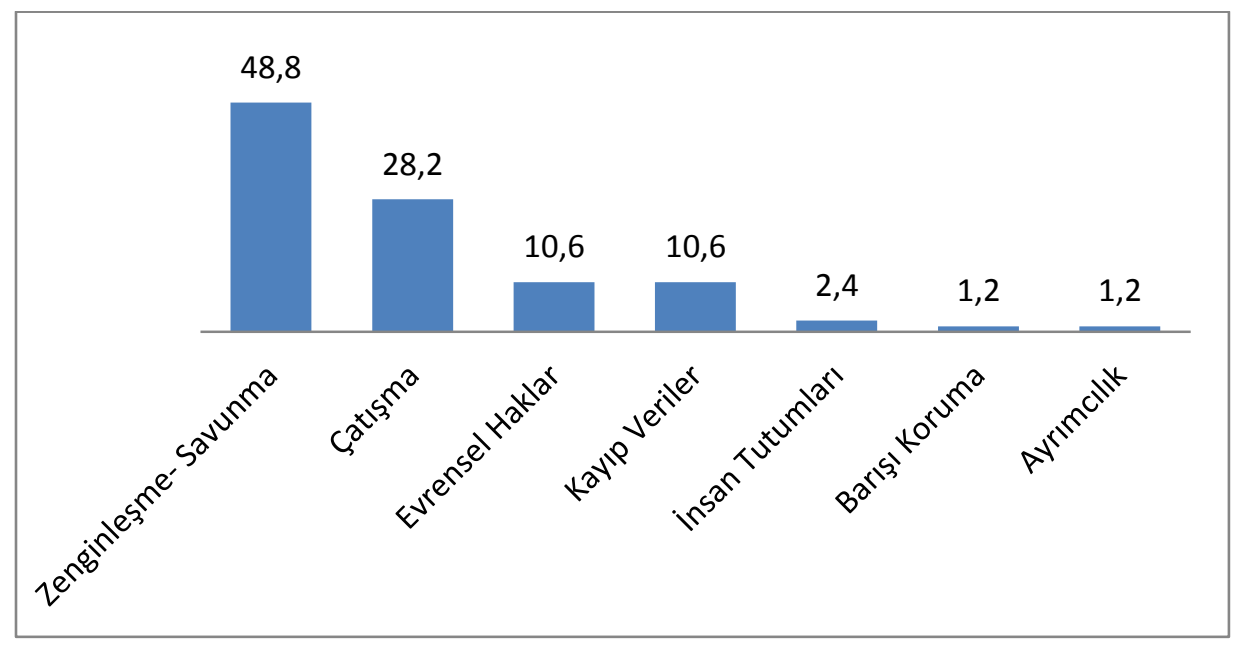

Grafik 12. On Beş Yaşında Bir Çocuğun Neden Savaşa Katılmamak Yönünde Tutum Gösterebileceği ile İlgili Öğrencilerin Görüşler 
Grafik 12 'te görüldüğü gibi on beş yaşındaki çocuk neden savaşa gitmek istemeyebilir sorusuna öğrenciler \% 48.8 oranında dış karakter (Kategori 1) kategorisinde cevap vermiştir.

“Okumak istediği için” (İHL, E). "Ölümden korktuğu için yaşıtlarl gibi yaşamak istediği için gitmek istemeyebilir" (GL, B). "Ana sevgisi ve korku yüzünden Musa savaşa gitmek istemeyebilir” (GSSL, E). “15 yaşındaki çocuk fayda sağlamaz” (GSSL, E).

Öğrenciler, ikinci sırada (\% 26.3) negatif sonuçlarla düşüncelerini açıklamıştır.

"Bir çocuk için savaş çok kapsamlıdır. Savaşırken ölebileceğini düşündüğü için” (GL, E). "On beşindeki çocuk hayatını kaybetmek istemez, ailesinden ve sevdiklerinden uzak kalacak" (GSSL, E).

Birinci ve ikinci kategorilerde benzer özellikler toplanmıştır. Çocuğun yaşını ve geleceğini öğrenciler göz önünde bulundurarak cevap vermiştir.

Öğrenciler \% 11.3 oranında ise çocuk ile ülkesi arasında görüş farkı olabileceğini dile getirmiştir.

"Yanlış eğitim olabilir, çocuk ülkesiyle sorun yaşayabilir” (FL, E). “15 yaşındaki çocuk bencil olabilir, umursamaz olabilir” (IHHL, B). "15 yaşındaki çocukta vatan bilinci yoksa ya da ülkesine kendisini ait hissetmiyorsa olabilir” (ML, B).

Öğrenciler dördüncü sırada \% 2.5 oranında olumsuz duygulara 
yoğunlaşmıştır.

"Savaş oyun değildir! Cesaret, güç, kuvvet, direnç ister" (GL, B).

Öğrenciler çocuğun savaşı ve şiddeti reddedeceği (Kategori 7), bu yüzden de savaşa gitmek istemeyeceği ihtimaline ise katılmadıklarını belirtmişlerdir.

\section{Ortaöğretim Öğrencileri 20. ve 21. Yüzyılda Meydana Gelen} Hangi Savaşlar Hakkında Bilgi Sahibidir ve Günümüzdeki Savaşların Nedenlerine İlişkin Görüşleri Nelerdir?

Araştırmanın ikinci sorusu yirminci ve yirmi birinci yüzyılda yaşanmış savaşlar ve bu savaşların nedenlerine ilişkin görüşlerinin ne olduğudur. Yirminci yüzyıl birçok kanlı savaşa sahne olmuştur. Araştırmaya katılan öğrenciler ise yaş itibari ile 20. yüzyılın son çeyreğinde dünyaya gelmişlerdir. Bu yüzyılı çocuk olarak tanımlamışlardır. Öğrencilerin hangi savaşlardan haberdar oldukları ile ilgili sorular sorulmuştur. Yirminci ve yirmi birinci yüzyılda yaşanan savaşların çok sayıda olması nedeniyle öğrencilerin verdikleri cevaplar tablo ile gösterilmiştir. Grafiklere başvurulmamıştır.

\section{Yirminci yüzyılda hangi savaşlar olmuştur?}

Öğrencilerin yirminci yüzyılda meydana gelen savaşlara verdikleri cevaplardan beş büyük savaş bir grupta toplanmıştır. Bu grupta sadece ABD-Sovyetler Birliği soğuk savaşı diğer savaşlar gibi sıcak çatışmalar şeklinde geçmemiştir. Ancak iki devlet arasındaki rekabet çeşitli şekillerde insanların ölümüne neden olmuş, silahlanma yarışının zirveye çıkmasına neden olmuştur. 
Tablo 1. "Yirminci Yüzyılda Hangi Savaşlar Oldu" Sorusuna Öğrencilerin Verdikleri Cevaplar

\begin{tabular}{lcc}
\hline 20. Yüzyılda Ülkeler Arasındaki Savaşlar & f & \% \\
\hline İkinci Dünya Savaşı & 41 & 33.8 \\
Birinci Dünya Savaşı & 37 & 30.5 \\
Kurtuluş Savaşı & 27 & 22.3 \\
Balkan Savaşları & 9 & 7.4 \\
ABD-Rusya Soğuk Savaşı & 7 & 5.7 \\
Toplam & 121 & 100 \\
\hline
\end{tabular}

Tablo 1'de görüldüğü gibi öğrenciler 20. yüzyılda hangi savaşlar oldu sorusuna öğrenciler en fazla "İkinci Dünya Savaşı” oldu cevabını vermişlerdir. Oppenheimer, Hagglund ve Hakvoort'un (1998) Hollandalı öğrencilerle yaptığı çalışmada da öğrencilerin Hollanda tarihinde savaşlarla ilgili en fazla İkinci Dünya Savaşı’yla ilgili farkındalıklarını göstermektedir.

\section{Ülkeler arasındaki savaş}

Öğrencilerin ülkeler arasındaki savaşlarla ilgili cevapları dokuz kategoride toplanmıştır. Bu grupta yer alan savaşlarda Soğuk Savaş döneminde yaşanan mücadelelerin de etkisi büyüktür. Öğrencilerin ülkeler arasındaki savaşlara verdikleri frekanslar Tablo 2'de verilmiştir. 
Tablo 2. Öğrencilerin 20. Yüzyıldan Günümüze Ülkeler Arasında Olan Savaşlara İlişkin Cevapları

\begin{tabular}{lcc}
\hline Ülkeler & $\mathbf{f}$ & $\boldsymbol{\%}$ \\
\hline I. ve II. Körfez Savaş1 & 30 & 35.7 \\
İsrail- Arap (Misır-Suriye-Filistin) & 18 & 21.4 \\
Kore & 12 & 14.2 \\
ABD-Afganistan & 7 & 8.3 \\
İran ve Irak & 5 & 5.9 \\
ABD-Vietnam & 4 & 4.7 \\
Hindistan-Pakistan & 3 & 3.5 \\
Sovyet-Afganistan & 3 & 3.5 \\
Rusya-Gürcistan & 2 & 2.3 \\
Toplam & 84 & 100 \\
\hline
\end{tabular}

Tablo 2'deki verilere bakıldığı zaman Körfez Savaşı'nın öğrenciler tarafindan en fazla oranda bilindiğini görmekteyiz. Bunun nedeni bu savaşın daha yakın zamanda olmasıdır. Körfez Savaşı'nın etkileri günümüzde Irak'ta iç çatışma olarak da devam etmektedir. Bunun gibi bir örneği İsrail ile Filistin arasındaki yaşanan çatışmalarda görmekteyiz. Bunun yanında öğrenciler Sovyet-Afganistan, ABD-Afganistan arasındaki savaşların yaşandığını da belirtmişlerdir. Öğrencilerin belirttikleri Rusya-Gürcistan savaşı ise çalışma başladıktan sonra olmuştur. Hakvoort (1996) Hollanda'da yaptığı çalışmada öğrenciler ülkeler arasındaki savaşlara en fazla oranda Körfez Savaşı ile Yugoslavya'da meydana gelen iç savaşı örnek vermişlerdir. Daha sonra Sovyetler Birliği, Güney Afrika, İsrail ve İran'da meydana gelen ça- 
tışmalardan haberdar olduklarını söylemişlerdir.

\section{Bir ülkenin dağılmasıyla yaşanan savaşlar}

Bir ülkenin dağılması ile yaşanan savaşlar üç kategoride toplanmıştır. Bu ülkeler komünizmin çökmesi nedeniyle birliği oluşturan devletlerin başta toprak kavgası olmak üzere çeşitli nedenleri olan savaşlardır. Öğrencilerin bir ülkenin dağılması ile ilgili verdikleri cevapların frekansları aşağıda verilmiştir.

Tablo 3. Öğrencilerin 20. Yüzyılda Bir Ülkenin Dağılmasıyla Gerçekleşen Savaşlara Verdikleri Cevaplar

\begin{tabular}{lcc}
\hline Ülkeler & f & \% \\
\hline Yugoslavya (Bosna Hersek-Sirbistan-Hırvatistan) & 3 & 33.3 \\
Azerbaycan-Ermenistan (Karabağ) & 3 & 33.3 \\
Rusya (Litvanta-Estonya-Letonya), Ukrayna & 3 & 33.3 \\
Sovyetlerin Dağılması & & \\
Toplam & 9 & 100
\end{tabular}

Tablo 3'te görüldüğü gibi öğrenciler bir ülkenin dağılması sonucu yaşanan savaşlarla ilgili üç ülke örneğinde cevapları vermişlerdir. Öğrenciler Yugoslavya'nın dağılması ve Sovyetlerin dağılması ile ilgili verdikleri cevaplar eşittir. Ortaöğretim öğrencilerinin Sovyetlerin dağılmasıyla Rusya ve diğer Slav ülkeleri arasında yaşanan savaşlardan da haberdar oldukları göze çarpmaktadır.

\section{İç çatışmaların ve ayaklanmaların olduğu ülkeler}

Araştırmada öğrencilere iki ülke arasında olan savaşların yanında 
iç savaş ve çatışma yaşanan ülkeleri bilip bilmedikleri de sorulmuştur. Öğrenciler düşük frekanslarda olmak üzere dünyanın çeşitli bölgelerinde yaşanan savaşlarla ilgili cevaplar vermişlerdir. Öğrencilerin cevaplarının frekansları ve yüzdelik oranları aşağıda verilmiştir.

Tablo 4. Öğrencilerin İç Savaş, Çatışma ve Ayaklanmaların Olduğu Ülkelere Yönelik Cevapları

\begin{tabular}{lcc}
\hline Ülkeler & f & \% \\
\hline Filistin & 11 & 25 \\
İsrail & 6 & 13.3 \\
İran & 5 & 11.1 \\
Pakistan & 4 & 8.8 \\
Lübnan & 3 & 6.6 \\
Cezayir & 2 & 4.4 \\
Çin & 2 & 4.4 \\
İspanya & 2 & 4.4 \\
Arabistan & 1 & 2.2 \\
Etiyopya & 1 & 2.2 \\
Güney Amerika(Şili) & 1 & 2.2 \\
Fildişi sahilleri & 1 & 2.2 \\
Hindistan (Sikhks- İndu) & 1 & 2.2 \\
Kenya & 1 & 2.2 \\
Güney Amerika & 1 & 2.2 \\
Kondras & 1 & 2.2 \\
Nijerya & 1 & 2.2 \\
Sudan & 1 & 2.2 \\
Toplam & 45 & 100 \\
\hline
\end{tabular}


Tablo 4 incelendiği zaman öğrencilerin en fazla Filistin cevabı verdikleri görülmüştür. Hakvoort, Hagglund ve Oppenheimer (1998)'in İsveçli ve Hollandalı çocuklarla yaptığı çalışmada öğrenciler Kuzey İrlanda, Hindistan, Güney Afrika ve Avusturalya'da iç savaşların ya da çatışmaların olduğunu belirtmişlerdir. Bu çalışmada ise Hindistan'da iç savaş ve ayaklanmaların olduğunu bir öğrenci belirtmiştir. Kuzey İrlanda, Güney Afrika ve Avustralya ile ilgili bir cevap verilmemiştir.

\section{Günümüzdeki savaşlar ve çatışmalar}

Günümüzdeki savaş ve çatışmalarla ilgili öğrencilerin bilgilerine baş vurulmuştur. Öğrenciler sekiz devlette savaş ya da iç çatışma yaşandığını vurgulamışlardır. Öğrencilerin bu ülkelerle ilgili verdikleri cevapların frekansları Tablo 5 'te belirtilmiştir.

Tablo 5. Öğrencilerin Günümüzde Savaş ve Çatışma Yaşanan Ülkelerle İlgili Cevapları

\begin{tabular}{lcc}
\hline Ülkeler & $\mathbf{f}$ & $\mathbf{\%}$ \\
\hline Libya & 38 & 30.6 \\
Suriye & 27 & 21.7 \\
Misir & 24 & 19.3 \\
Irak & 18 & 14.5 \\
Tunus & 9 & 7.2 \\
Afganistan & 6 & 4.8 \\
Yemen & 1 & 0.8 \\
Yunanistan & 1 & 0.8 \\
Toplam & 124 & 100
\end{tabular}


Tablo 5'ten anlaşılacağı üzere öğrenciler gündemde olduğundan dolayı Libya, Mısır ve Suriye'deki çatışmalara dikkat çekmişlerdir. Araştırmanın yapıldığı Ekim ayında Mısır'daki olaylar büyük ölçüde yatışmış fakat Libya ve Suriye'deki çatışmalar bütün şiddetiyle devam etmektedir. Öğrenciler, Irak'ta da iç savaşın ve çatışmaların devam ettiğini vurgulamışlardır. Bir öğrenci farklı olarak Yunanistan'da ekonomik gösterileri iç savaş olarak adlandırmıştır.

\section{İnsanlar niçin savaşır?}

Araştırmanın on birinci alt sorusu öğrencilerin günümüzdeki savaşların nedenleri ile ilgili düşüncelerini açığa çıkarmaya da yöneliktir. Öğrencilerin cevapları dokuz kategoride ve kategorilerin alt boyutlarında değerlendirilmiştir. Savaşların nedenlerine yönelik kategorilere verilen cevapların yüzdeleri ve cevap örnekleri aşağıda belirtilmiştir.

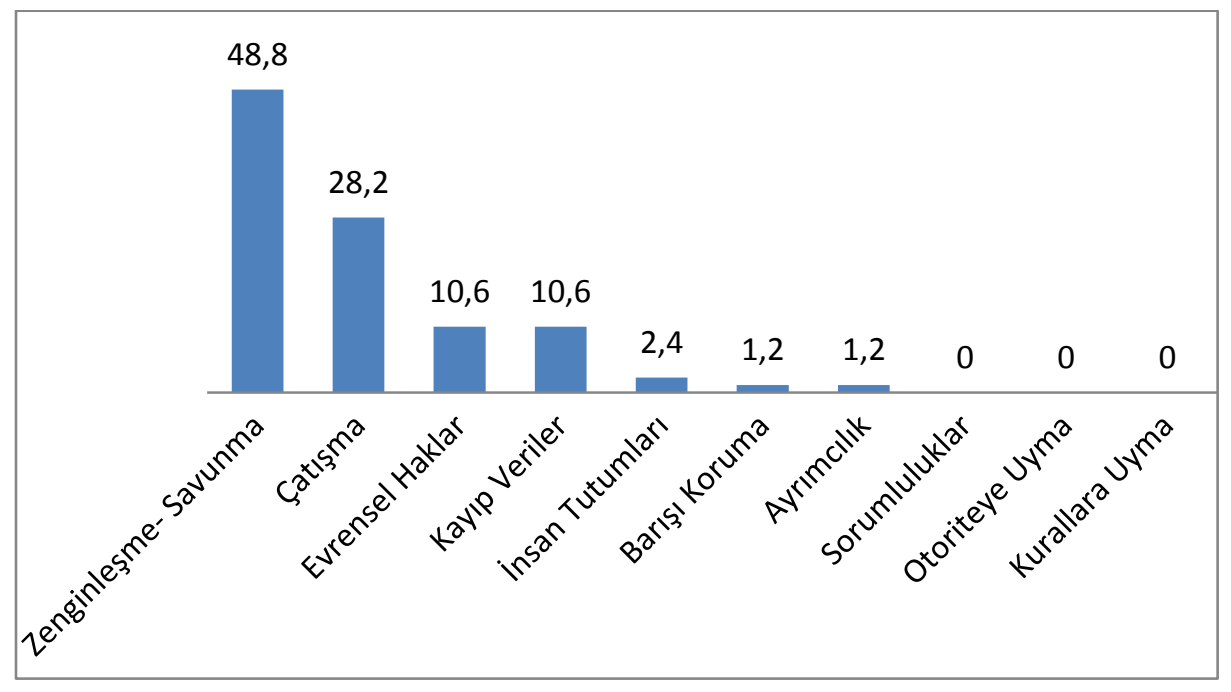

Grafik 13. Günümüzde Savaşların ve Çatışmaların Nedenlerine Dâir Öğrencilerin Görüşleri 
Günümüzde savaşların temel nedeninin ne olduğu yönündeki soruya öğrencilerin cevapları en fazla oranda (\% 45.9) kategori 5 'te toplanmıştır. Bu kategori zenginleşme alt boyutunu içeren kategoridir. $\mathrm{Bu}$ kategoride öğrenciler özellikle savaşların petrol için yapıldığına dikkat çekmişlerdir.

“Temel nedeni, petrol ve karşıt görüşler. Dış ülkelerin oralardaki kaynaklara sahip çıkmak istemesi. Sömürgeciliğe son verilmeli, ülkeler aç gözlülüğ̈̈ bırakmalı”(AL, E). “Günümüzde savaşların en önemli nedeni ekonomiktir. Bugün de savaşların yoğunlukta olduğu yerler Ortadoğu'daki petrollerin çok olduğu yerlerdir” (GL, B). "Başka insanlar onların değerlerini kullanıyorlar, petrollerini kullanıyorlar" $(F L, E)$. “ABD, dünya petrollerini elinde tutmak istiyor. ABD, Libya petrolünün Kaddafi 'nin elinde bulunmaması için NATO kisvesi altında bu ülkeye savaş açtı. Libya'da savaş Kaddafi'nin gitmesiyle olur”, (GSSL, B). “Bu ülkelerde zengin petrol kaynakları var, emperyalist devletler saldırıyor, ABD ve Ingiltere, Bu ülkelere barış gelmez. Savaş, tek tarafl zulüm var, sömürü var”(SBL, E).

Köhber Vakfı tarafından yapılan araştırmada öğrencilere "Avrupa dünyanın geri kalan kısmını sömüren ve ekolojik bakımdan suçlu bir grup beyaz ve zengin ülkedir” önermesine en güçlü bir biçimde katılan ülkeler Filistin (3.35), İsrailli Araplar (3.35) ve Türkiye (3.27) olmuştur. Her iki araştırmanın görüşleri de bu noktada paraleldir. Avrupa, Müslüman gençlerin gözünde, özellikle Müslüman ülkelerin zenginliklerini sömüren ülkeler topluluğu olarak düşünülmektedir. $\mathrm{Bu}$ gruba bugün Amerika Birleşik Devletleri de eklenmiştir. 
Öğrencilerin cevapları ikinci sırada ise kategori altıda toplanmıştır. Bu kategori iki ülke arasında ve bir ülkenin içinde yöneticilerle halk arasında olan çatışmaları içermektedir. Öğrencilerin tamamı ise bu kategoride halk ile yöneticiler arasında bir bağ olmadığını ve halkın yöneticileri istemediğini belirtmiştir. İç savaş diktatörlere karşıdır.

"Bu ülkeler diktatörlüğe karşı savaşlyorlar. Devlet başkanları istifa etmeliler" (AL, E).

Öğrenciler üçüncü sırada ise evrensel hakların olmadığını dile getirmiş̧ir.

"Çünkü bu ülkelerde demokrasi isteği var. Demokrasi yok, demokrasinin yürütülmesiyle barış gelecek" $(A L, B)$. "Diktatörlükle yöneltiliyorlar. Bu ülkelere barış, iki tarafin da destekleyebileceği insan gelirse ve meclis kurulursa, yani demokrasi gelmeli" (SBL, B). "Libya'da ve Suriye'de halk özgürlük istiyor, bu ülkede halkn istekleri yerine gelirse barışolur. Demokrasi gelince barış olacak" (GSSL, E).

Öğrenciler \% 2.4 oranında ise savaşın nedenlerini insan tutumlarına bağlamaktadır.

"Çıkar, zihniyet, öç" (GL, E).

Öğrenciler \% 1.2 oranında da ayrımcılıklar ve barışı koruma kategorisini seçmiş̧ir.

"ABD-İsrail-AB üçlüsünün klşkırtmaları" (GL, B). 


\section{Sonuç ve Öneriler}

Araştırmanın sonuçlarını değerlendirildiğinde öğrencilerin savaş ve barış tanımlamalarında kategorilerde geniş bir dağılım oluşmuştur. Öğrenciler savaş ve barış kavramlarını geniş bir yelpazede tanımlamıştır. Ortaöğretim öğrencilerin çoğunluğu barışı olumlu duygularla tanımlamıştır.

Ortaöğretim öğrencilerine göre dünyanın barış dolu bir yer olması için ne yapılabileceği sorulduğunda öğrenciler paylaşımın ve fakir bölgelere yardım göndermenin önemine dikkat çekmiştir. Öğrenciler yeryüzünde barışın olması için insanlara ayrımcılık yapılmaması gerektiğinin önemine de işaret etmiştir. Öğrenciler bir ülkede iç savaş olması durumunda yöneticilerin halkın arasına katılmasına dikkat çekmiştir. Ortaöğretim öğrencileri başka bir ülke ile savaş yapılması durumunda ise barış getirmenin savaşı kazanmakla mümkün olduğuna dikkat çekmiştir. Öğrenciler yine 15 yaşında bir çocuğun savaşa gidip gitmemesi kararına çoğunlukla gitmeli cevabını vermiştir. Veriler ortaöğretim öğrencilerinin ülke savunmasına özel bir önem verdikleri sonucu da ortaya çıkmıştır. Öğrenciler en yakın arkadaşlarının başka bir sınıf arkadaşıyla kavga etmesi durumunda ve savaş yaşayan iki ülkenin barış yapmasında en önemli faktörün bir ara bulucu olduğuna dikkat çekmiştir. Bu bulgulardan hareketle öğrencilerin dünya üzerindeki barış için çalışan Birleşmiş Milletler, UNESCO gibi kurumların çalışmalarına olumlu baktıkları anlaşılmaktadır.

Öğrenciler "20. yüzyılda hangi savaş olmuştur?” sorusuna ilk sırada İkinci Dünya Savaşı, ikinci sırada Birinci Dünya Savaşı, üçüncü 
sırada ise Kurtuluş Savaşı cevabını vermiştir. Kurtuluş Savaşı Türk milletini daha fazla ilgilendirdiği ve tarih programlarda Kurtuluş Savaşı'na özel önem verildiği hâlde Kurtuluş Savaşı'nın üçüncü sırada bilinmesinin nedeni öğrencilerin Kurtuluş Savaşı'nı, Birinci Dünya Savaşı'nın içerisinde görüp bu savaşın kapsamı içinde cevap vermelerine yorulabilir. Öğrenciler devletler arasındaki savaşlara en fazla Körfez Savaşları cevabını vermiştir. Öğrenciler daha sonra özellikle İsrail ve Filistin arasındaki çatışmaları merkeze alarak İsrail-Arap Savaşlarını bildiklerini söylemiştir. Öğrenciler üçüncü sırada ise Kore Savaşı'na vurgu yapmıştır. Bunun en önemli nedeni Türkiye'nin, Kore Savaşı'na asker göndermesi olarak yorumlanabilir. Öğrenciler en az oranda ise Rusya ile Gürcistan arasında yaşanan savaşa dikkat çekmiştir. Bu savaşı çok az öğrencinin bilmesi savaşın çok kısa sürmesi, öğrencilerin bu savaş yaşanırken, savaş haberlerine odaklanacak yaşta olmamaları ve bu savaşın tarihe geçmek için çok kısa zaman önce yapılmış olmasına yorulabilir. Rusya-Gürcistan Savaşı çalışma başladıktan sonra iki devlet arasında yaşanan tek savaştır. Öğrenciler bir ülkenin dağılmasıyla çıkan savaşlara eşit oranda cevap vermiştir. Ortaöğretim öğrencileri Bosna, Karabağ ve Sovyetlerin dağılmasıyla Rusya ve diğer ülkelerle yaşanan savaşı eşit oranda bilmiştir. Burada dikkat çeken nokta öğrencilerin Sovyetler Birliği’nin dağılmasıyla Rusya ve diğer Slav kökenli devletler arasındaki savaşa ilişkin farkındalık düzeyidir.

Ortaöğretim öğrencileri iç savaşların yaşandığı ülkelere en fazla oranda Filistin ve ikinci sırada ise İsrail cevabını vermiştir. Öğrenciler 
üçüncü sırada ise İran cevabını vermiştir. Öğrencilerin İsrail ve Filistin'de iç savaş yaşandığına yönelik cevaplarında iki ülke arasında yaşanan çatışmaların da etki ettiği düşünülmektedir. Öğrenciler üçüncü sırada ise İran'da iç savaş yaşandığını dile getirmiştir. Öğrenciler iç savaş yaşanan Afrika ülkelerine ise çok düşük oranda cevap vermiştir. Öğrencilerin bu cevapları değerlendirildiği zaman savaşlarla ilgili bilgilerinin oluşmasında basın televizyon ve internetin önemli bir etki yaptı̆g görülmüştür. Lise öğrencileri arasında Afrika tarihini öğrenmede eksiklikler olduğu ortadadır. Öğrenciler günümüzde iç savaş yaşanan bölgeler olarak Libya, Mısır ve Suriye'yi örnek vermişlerdir. Uygulamanın yapıldığı 2011 yılı Ekim ayında basında Libya ile ilgili haberler önemli yer tutmaktadır. Mısır'da olan çatışmalar yeni durmuştur ve Suriye'deki çatı̧smalar da şiddetlenme aşamasına girmiştir. Öğrenciler bu ülkelerden sonra Irak daha sonra ise "Arap Baharı" adı verilen yönetime karşı ayaklanmaların başladığı Tunus cevabını vermiştir. Bir öğrenci Yemen'de iç savaş yaşandığına dikkat çekerken bir öğrenci de Yunanistan'daki çatı̧̧malara dikkat çekmiştir. Ortaöğretim öğrencilerine göre günümüzde yaşanan iç savaşların en büyük nedeni büyük devletlerin diğer ülkelerin petrolüne el koyma isteğinden kaynaklanmaktadır. Öğrenciler ikinci sırada bir ülkede yaşayan halk ile ülkeyi yönetenler arasındaki sorunlara dikkat çekmiştir. Öğrenciler üçüncü sırada ise bu ülkelerde evrensel hakların olmamasına dikkat çekmiş̧tir. Bu bulguları değerlendirdiğimizde öğrencilerin yarıya yakını "Arap Baharı" adı verilen eylemlerin dış destekli ve büyük güçler tarafından organize edildiğini düşünmektedir. Ancak ikinci sırada ise bu ülkelerde diktatörlüğün ve evrensel hakların olmaması nedeniyle iç 
savaşlar yaşandığına dikkat çekilmiştir. Yani, öğrencilerin son zamanlarda Arap coğrafyasında yaşanan olaylara ilişkin görüşleri yoğun olarak iki kategoride toplanmıştır.

Araştırmanın literatürü değerlendirildiğinde iç savaşları anlatan kaynakların sayısında yetersizlik olduğu gözlenmektedir. İç savaşlarla ilgili akademik çalışmalara ihtiyaç duyulmaktadır.

Türkiye'de barış ve savaş kavramının hangi yaşlarda anlaşılabildiğiyle ilgili akademik çalışmaların yapılması, tarih eğitimi alanına katkı sağlayacaktır.

Barış ve savaş kavramını öğrencilere daha iyi anlatabilecek yöntem ve tekniklerin sınanması gerekmektedir.

Savaşların ve antlaşmaların öğrenciler tarafından nasıl algılandığıyla ilgili çalışmalara ihtiyaç duyulmaktadır. Bu çalışmalar yapılırken savaşların ve barışların tek tek ele alınıp değerlendirmesinin önemli olduğu düşünülmektedir.

\section{Kaynakça}

Akad, M.T. (2011). 20. yüzyıl savaşları. İstanbul: Kastaş Yayınevi.

Âlvik, T. (1968). The developmet of views on conflict, war, and peace among school children. Journal of Peace Research, 5(2), 171-195.

Barton, K. C. ve McCuly, A. W. (2005). History, identity, and the school curriculum in Northern Ireland: an empirical study of secondary student's ideas and perspective. Journal of Curriculum 
Studies, 37(1), 85-116.

Berti, A. E ve Vanni, E. (2000). Italian children's understanding of war: A domain-spesific aproach. Social Development, 9(4), 478-486.

Cairns, E., McLernon F., Moore W., ve Hakvoort, I. (2006). The impact of the peace process in Northern Ireland on children's adolescents' ideas about war and peace. S. McEvoy, (Ed.), Troublemakers and peace makers, youth and post-accord peace buildings içinde (117-137). Indiana: Notre Dame.

Cantril, H., Rugg, D. ve Williams, F. (1940). America faces war: Shift opinion. Public Opinion Quarterly, 4(4), 651-656. 27/06/2010, http//www.jstor.org/stable/2744857.

Cooper, P. (1965). The development of the concept of war. Journal of Peace Research, 2(1), 1-17.

Coşkun, S. (2008). Çocuk ve barış: Çocuklar nasıl bir dünya istiyor? M. Safran ve D. Dilek, (Ed.), 21. yüzyllda kimlik, vatandaşlık ve tarih eğitimi içinde (286-301). İstanbul: Yeni İnsan Yayınevi.

Covell, K., Rose-Krasnor, L., ve Fletcher, K. (1994). Age differences in understanding peace, war, and conflict resolution. International Journal of Behavioral Development, 17(4), 717-737.

Duffy, E. (1941). Attitudes of parents and daughters toward war and toward the treatment of criminals. The Psychologial Record, 4(23), 367-372.

Grotius, H. (2011). Savaş ve barlş hukuku. (S.L. Meray, Çev.). İstanbul: Kurtiş Matbaası (Orijinal çalışma basım tarihi 1625).

Gwartney, P. A. ve Lach D. H. (1991). Sex Differences in Attitudes toward Nuclear War. Journal of Peace Research, 28(2), 161-174. 
Hakvoort, I. ve Oppenheimer, L. (1993). Children and adolescents' conceptions of peace, war and strategies to attain peace: A Dutch case study. Journal of Peace Research, 30, 65-77.

Hakvoort, I. (1996). Conceptualization of peace and war from childhood through adolesence: A social-cognitive development approach, Universiteit Van Amsterdam.

Hakvoort, I. (1997). Interview- Manual, Semi Structured Interview-Procedure to Assess the Conceptions of Peace, War and to Attain Peace, University of Amsterdam, Netherlands.

Hakvoort, I. (1997). Conceptions of Peace, War and Strategies to Attain Peace, University of Amsterdam, The Netherlands.

Hakvoort, I., Hagglund, S., ve Oppenheimer, L. (1998). Dutch and Swedish adolescents' understanding of peace and war. Adolescents, Cultures and Conflicts: Growing up in Contemporary Europe (75-105). New York: Garland.

Hanson, V. D. (1999). The dilemmas of the contemporary military historian, reconstruction history. E. fox-Genovese ve E. L. Quinn, (Ed.), The Emergence of a New Historical Society içinde (189-201), New York: Routledge.

Karasar, N. (2005). Bilimsel Araştırma Yöntemi, Ankara: Nobel Yayın Dağıtım.

Kuhlen, R. (1943). Attitudes toward enemy and allied countries. The Journal of Abnormal and Social Psychology. The American Psychology Association, 38, 277-283.

Oruç, Ş. (2002). İlkögretim İkinci Kademede Görev Yapan Tarih Öğretmenlerinin Savaş Konularının Öğretimine İlişkin Tutumlarl. Yayımlanmamış yüksek lisans tezi, Gazi Üniversitesi Eğitim Bilimleri Enstitüsü. 
Pihlblad, C. T. (1935). Student attitudes toward war. Sociology and Social Reserach, 10(2), 249-254.

Porter, E. (1926). Student opinion on war: An investigation. Yayınlanmamış doktora tezi, The University of Chicago.

Preston, R. C. (1942). Children's reactions to a contemporary war situation. Bureau of Publications Teacher College, New York: Colombia University.

Rood, J. (1985). Pre-school children's understanding of war. Early Child Development and Care, 22, 109-121.

Rosell, L. (1968). Children's views of war and peace. Journal of Peace Research, 5(3), 268-276.

Souza, L. K, Sperb T. M. ve McCarty S. (2006). Brazilian children's conceptions of peace, war and violence. Peace and Conflict: Journal of Peace Psychlogy, 12(1), 49-63.

Stagner, R. (1942). Some factors related to attitude toward war. The journal of Social Psychology, 16, 131-142.

Salomon, G. (2004). Does peace education make a difference in the context of an intractable conflict? Peace and Conflict of Peace Psychology, 10(3), 257-274.

Tashakkori A, ve Teddlie, C. (2009). Integrating qualitative and quantative approaches to research. L. Bickman ve D. J. Rog (Ed.), Applied Research Design (283-317). Los Angeles: Sage publications.

Tekeli, İ. (1998). Tarih bilinci ve gençlik, İstanbul: Tarih Vakfı Yurt Yayınları. 
Vriens, L. ve Aspeslagh, R. (1985). Peace education as alternating between the person and structle. The History and Social Science Teacher, 20(3/4), 11-19.

Yıldırım, A ve Şimşek, H. (2006). Sosyal bilimlerde nitel araştırma yöntemleri (5. baskı). Ankara: Seçkin Yayıncılık.

Wagner, R.V. (1988). Distinguishing between positive and negative approaches to peace. Journal of Social Issues, 44(2), 1-5.

Wright, Q. (1941). A Study of War, Vol. I. Chicago/London: The University of Chicago Press. 